I b S

IBS WORKING PAPER 04/2017 JUNE 2017

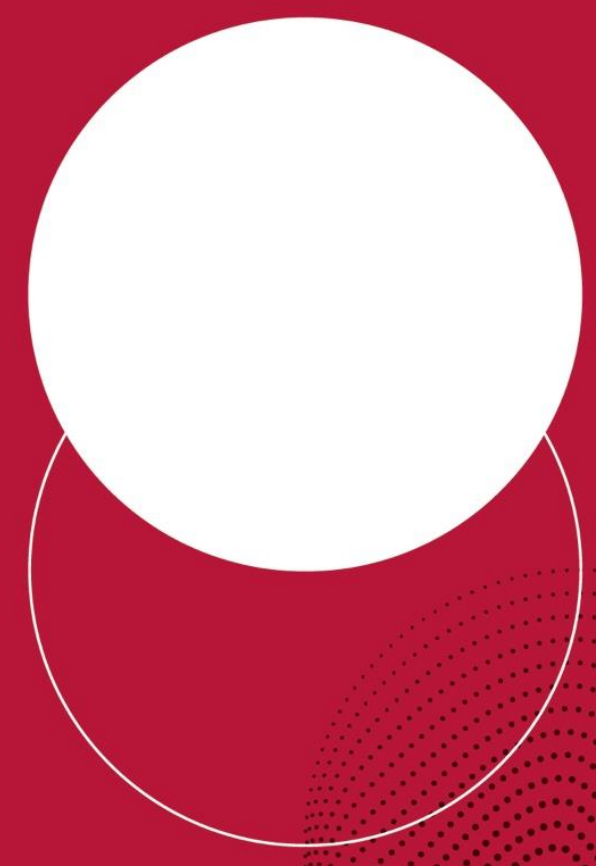

TEMPORARY EMPLOYMENT BOOM IN POLAND - A JOB QUALITY VS. QUANTITY TRADE-OFF?

Piotr Lewandowski Marek Góra Maciej Lis

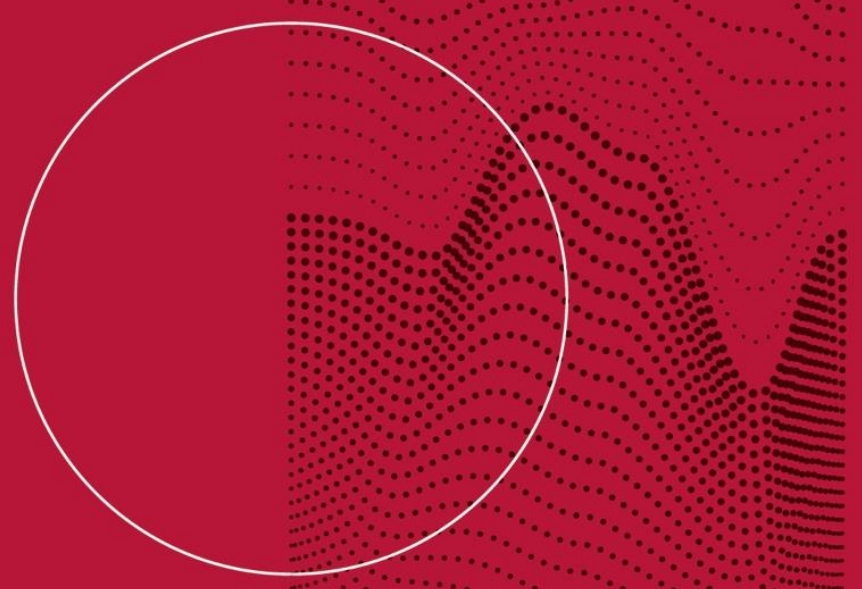




\title{
TEMPORARY EMPLOYMENT BOOM IN POLAND - A JOB QUALITY VS. QUANTITY TRADE-OFF? $?^{\circ}$
}

\author{
Piotr Lewandowski \\ Marek Góra* \\ Maciej Lis"
}

\begin{abstract}
Between 2002 and 2015, temporary employment in Poland more than doubled. Poland became the country with the highest share of temporary jobs in the EU. In this paper, we study how this process affected job quality and job quantity. We analyse the gaps between temporary and permanent workers in six dimensions of jobs quality, adopting measures proposed by the OECD and Eurofound. Of these gaps, the differences in earnings quality, job security, and work scheduling quality were the most pronounced. Job quality has improved for both groups of workers, but the gaps have not closed completely. Firms in Poland prefer to employ temporary rather than permanent workers because of the lower firing costs, tax wedges, and wages associated with temporary contracts. We use a stylised labour demand model to quantify the upper bound of a potential job creation effect due to lower labour costs incurred through the use of temporary contracts. We find that this effect did not exceed $4 \%$ of dependent employment in 2015 . We cannot rule out the possibility that the net employment effect was zero. Our findings show that even if the availability of less-costly temporary contracts caused some additional jobs to be created, temporary workers suffered from lower job quality in several dimensions.
\end{abstract}

Keywords: job quality, temporary employment, segmentation

JEL: J41, J28, J81

- We thank Jan Gromadzki and Aneta Kiełczewska for their excellent research assistance. We thank Lucas Ronconi as well as the participants of Jobs and Development Conference in Washington, D.C., and the IZA/OECD/World Bank/UCW Workshop “Job Quality in Posttransition, Emerging and Developing Countries" for their insightful comments. This paper was financially supported by the Network for Jobs and Development initiative under the auspices of the World Bank. The usual disclaimers apply. All errors are our own.

- Institute for Structural Research, Warsaw, and IZA, Bonn. E-mail: piotr.lewandowski@ibs.org.pl. Corresponding author.

* Warsaw School of Economics, Warsaw, Poland, and IZA, Bonn. E-mail: marek.gora@sgh.waw.pl.

- Institute for Structural Research, Warsaw, Poland. E-mail: maciej.lis@ibs.org.pl. 


\section{Introduction and motivation}

Since the early 2000s, temporary employment in Poland has grown substantially; and in 2014, Poland became the EU country with the highest share of temporary workers ( $27 \%$ of dependent employment). Temporary contracts became common in both the private and the public sector, among men and women, and across all educational and age groups. In Poland - unlike in, for example, Spain in the 1980s - the rise in the incidence of temporary employment was not triggered by a substantial change in employment protection legislation. The trend began in the early 2000s, when the unemployment rate was above $20 \%$ and the safety net was weak (Maciejewska et al., 2016). These conditions appear to have reduced the bargaining power of workers and increased their acceptance of temporary contracts (Baranowska and Lewandowski, 2007). In Poland, temporary contracts can be used to employ people for long periods, and are easier to terminate than permanent contracts. Some types of temporary contracts permit lower social security contribution levels, and were not covered by minimum wage rules until 2016. The confluence of these factors created incentives to use temporary contracts (Arak et al., 2014).

Since the early 2000s, unemployment in Poland declined significantly (from 3.4 million in 2002 to 1.3 million in 2015) while total employment increased (from 13.5 million in 2002 to 15.8 million in 2015). ${ }^{1}$ of the 2.1 million total net jobs created between 2002 and 2015, 2.0 million were temporary jobs. The parallel reduction in unemployment and the dominant contribution of temporary jobs to net employment growth resulted in Polish policy-makers taking an ambiguous stance of towards temporary contracts. For example, between 2002 and 2016, no regulatory changes aimed at limiting the use of temporary contracts were introduced.

In this paper, we try to answer two questions. The first question is related to job quality: namely, how did job quality evolve among temporary and permanent workers between the early 2000s and the mid-2010s? The second question is related to job quantity: namely, was there any net employment effect of the temporary employment boom? We expand the traditional approach to analysing temporary jobs from the point of view of job insecurity by accounting for other dimensions of work conditions. We also quantify a potential trade-off between additional job creation and the potential drawbacks of temporary contracts that might have affected all of the individuals in these jobs.

We study multidimensional job quality among temporary and permanent workers using the recent methodologies of the OECD (Cazes et al., 2015, OECD, 2014) and Eurofound (Muñoz de Bustillo et al., 2011, Eurofound 2012, Hurley et al. 2013). We account for earnings quality, job security, development opportunities, job strain, long working hours, and the quality of work scheduling. We identify which of these dimensions are the most important in distinguishing between the quality of temporary and permanent jobs. To our knowledge, Arranz et al. (2017) is the only previous study that has analysed the gaps in job quality between temporary and permanent employment (in Italy and Spain). We account for aspects of job quality that are similar to those used in Arranz et al. (2017), but our measures are closer to those developed by the OECD (2014) and Cazes et al. (2015). We also juxtapose the gaps in job quality and their evolution over time with our calculation of the job creation effect attributed to the proliferation of temporary contracts.

\footnotetext{
${ }^{1}$ The question on temporary employment status was first introduced in the Polish LFS in 2002. Previously, the distinction was between regular work and casual work. The data in these two periods are not comparable. Temporary employment in Poland can be analysed in a consistent manner only from 2002 onwards.
} 
Although the job creation effect of temporary contracts in Poland has never been estimated, it appears that the belief that temporary jobs "allowed" for the decline in unemployment in Poland is shared by policy-makers (Chancellery of the Prime Minister 2011, Ministry of Administration and Digitization, 2013) and international organisations (OECD, 2006). These views contrast with those expressed in the literature on employment protection legislation (EPL) and labour market segmentation. Most theoretical models show that weaker EPL increases both job creation and job destruction, and thus has an ambiguous effect on employment and unemployment (Bentolila and Bertola, 1990, Cahuc and Postel-Vinay, 2001); although Hopenhayn and Rogerson (1993) found that stronger employment protections are associated with reduced firm entry, and therefore with reduced employment. Most previous empirical studies on this issue found that the effects of employment protection on employment and unemployment have been small (Bertola, 1990, Lazear, 1990) or insignificant (Nickel et al., 2005, Bassanini and Duval, 2009, review in Boeri 2011), especially when the enforcement of regulations is controlled for (Kanbur, Ronconi, 2016). Lazear (1990) found a significant effect on total employment, which was, however, substantially smaller than the effect on the substitution of permanent jobs with temporary jobs. Boeri and Garibaldi (2007) showed that the introduction of temporary contracts might lead to a transitory employment boom ("a honeymoon effect"), and found such an effect in Italy.

In this study, we use a stylised labour demand model to quantify the potential employment gains related to the temporary employment boom, with a focus on the cost differences between permanent and temporary contracts. The effects of the temporary employment boom on the labour market outcomes in Poland cannot be estimated directly due to the lack of an appropriate instrument for measuring these effects. The proliferation of temporary contracts was not preceded by any significant changes in the labour code. The legal conditions for using temporary contracts were identical for all agents, regardless of firm size, sector, or occupation. Thus, it is not possible to assess the causal impact of temporary contracts on employment using a natural or a quasi-natural experiment approach that employs instrumental variables, discontinuity design, or difference-in-difference; as was done in Angrist and Kruger (2001), Boeri and Jimeno (2005), Pereira (2003), and Van der Klaauw (2014).

We account for three sources of differences in the labour costs associated with permanent and temporary contracts in Poland. First, there are differences in the indirect costs of more stringent regulations on the termination of an open-ended contract that result from difficult-to-measure items such as the inability to lay off workers in case of reduced demand, severance payments, notice periods, the potential costs of resolving disputes, and the costs related to forgone wages (Hopenhayn and Rogerson, 1993, Lazear, 1990). Second, there are differences in the social security contribution levels (particularly for the employer) required by (some) temporary and open-ended contracts. Third, it has been noted in the literature that there is a wage penalty associated with temporary jobs (Boeri 2011), and that this penalty contributes to the total differences in wage levels in countries in which temporary jobs make up a large share of employment (Cazes and de Laiglesia, 2015). We parametrise these costs and use the resulting difference in the total cost of employing a worker with a particular contract type to calculate the upper bound of additional job creation allowed by these lower costs.

The paper is structured as follows. In the second section, we present the stylised facts on temporary employment in Poland. In the third section, we introduce the measures of job quality, discuss the results, and identify the key dimensions of the gap in the quality of temporary and permanent jobs. In the fourth section, we outline the labour demand model, which allows us to quantify the possible range of a potential job creation effect related to the use of temporary contracts. In the final section, we summarise our findings and draw conclusions that have implications for public policy. 


\section{Stylised facts on temporary employment in Poland}

\section{$2.1 \quad$ Regulatory and institutional setting}

Temporary employment takes three main forms in Poland: fixed-term employment contracts (based on the Labour Code), civil law contracts (not based on the Labour Code), and employment through temporary work agencies. While the last of these employment forms is regulated by a separate act, in principle temporary agency workers should be provided with the social security and minimum wage guarantees mandated under the Labour Code. Because the vast majority of individuals who are employed by temporary work agencies have some type of temporary contract with an agency (Lewandowski and Magda, 2017), we have chosen to focus on fixed-term and civil law contracts.

Table 1. Features of the various employment contracts in Poland

\begin{tabular}{|c|c|c|c|c|}
\hline \multirow[b]{2}{*}{$\begin{array}{l}\text { Benefits and rights } \\
\text { of workers }\end{array}$} & \multicolumn{2}{|c|}{ Labour Code contracts } & \multicolumn{2}{|c|}{ Civil law contracts } \\
\hline & $\begin{array}{l}\text { Permanent } \\
\text { (PC) }\end{array}$ & $\begin{array}{l}\text { Fixed-term } \\
\text { (FTC) }\end{array}$ & $\begin{array}{l}\text { Contract of mandate } \\
\text { (umowa zlecenie) }\end{array}$ & $\begin{array}{l}\text { Contract to perform } \\
\text { specified work } \\
\text { (umowa o dzieło) }\end{array}$ \\
\hline Social security contributions & Yes & Yes & $\begin{array}{c}\text { Yes, but can be relatively } \\
\text { low or may not apply to all } \\
\text { contracts signed by an } \\
\text { individual }\end{array}$ & No \\
\hline Health insurance & Yes & Yes & Yes & No \\
\hline Paid leave & Yes & Yes & No (upon agreement) & No (upon agreement) \\
\hline Minimum wage coverage & Yes & Yes & No (until July 2016) & No \\
\hline Period of notice & Yes* & $\begin{array}{c}\text { Yes, but } \\
\text { shorter than in } \\
\text { PC until } 2016\end{array}$ & Upon agreement & Upon agreement \\
\hline $\begin{array}{c}\text { Justification for terminating } \\
\text { contract }\end{array}$ & Yes & No & No & No \\
\hline Severance pay & Yes ${ }^{\star \star}$ & Yes ${ }^{\star \star}$ & Upon agreement & No \\
\hline \multicolumn{5}{|c|}{ Employment (millions of workers) } \\
\hline 2002 & 12.3 & 0.9 & \multicolumn{2}{|c|}{$0.6^{\star \star \star}$} \\
\hline 2015 & 12.6 & 2.5 & \multicolumn{2}{|c|}{$1.0 \star \star \star$} \\
\hline
\end{tabular}

Note*: The length of the notice period depends on the length of service in the enterprise. There are three statutory notice periods in Poland: two weeks if the worker has been employed for less than six months, one month if the worker has been employed between six months and three years, and three months if the worker has been employed for three years or more.

Note**: The amount of severance pay depends on the length of service in the enterprise. Workers employed for less than two years are entitled to severance pay equal to one month's salary, workers employed between two and eight years are entitled to severance pay equal to two months' salary, and workers employed for more than eight years are entitled to severance pay equal to three months' salary. Regulations regarding severance pay apply irrespective of the type of contract (TLC or PLC).

Note**: In the available data, civil law contracts are presented in a joint category only.

Source: Own elaboration based on Gatti et al. (2014).

There are two main reasons why both types of temporary contracts offer lower levels of job security than openended employment contracts in Poland. First, temporary contracts are concluded for a specific period of time. 
Second, this period can be long (there is no limit in the case of civil law contracts; and until 2016, there was no limit in the case of fixed-term contracts), but temporary contracts are easier to terminate than permanent contracts. In particular, the employer is not required to give a reason for the termination (Table 1). Importantly, the ability to terminate without cause is not addressed in the indices of employment protection legislation, like the OECD EPL index (Lewandowski and Magda, 2017).

The regulation of civil law contracts (contracts of mandate and contracts to perform specified work) is particularly weak (Table 1). Under these contracts, the minimum wage was not binding until July 2016; paid leave is not obligatory; and social security contributions can be lower than they are under employment contracts (or they may not apply at all), which translates into a total tax wedge that is lower than the tax wedge under employment contracts (Arak et al., 2014). ${ }^{2}$

Table 2. Main changes in labour laws in Poland between 2002 and 2016

\begin{tabular}{|c|c|c|c|}
\hline $\begin{array}{c}\text { Adoption } \\
\text { year }\end{array}$ & $\begin{array}{c}\text { Implementation } \\
\text { year }\end{array}$ & Policy field & $\begin{array}{c}\text { Effect on the strength of } \\
\text { regulation }\end{array}$ \\
\hline 2002 & 2003 & Collective dismissals & Decreasing \\
\hline 2002 & 2002 & Maximum duration of fixed-term contracts & Decreasing \\
\hline 2002 & 2003 & Procedural requirements & Decreasing \\
\hline 2003 & 2004 & Collective dismissals & Increasing \\
\hline 2003 & 2004 & Maximum number of renewals of fixed-term contracts & Increasing \\
\hline 2003 & 2003 & Notice and severance payments & Increasing \\
\hline 2003 & 2004 & Temporary agency work & Increasing \\
\hline 2004 & 2004 & Maximum number of renewals of fixed-term contracts & Increasing \\
\hline 2014 & 2016 & Social contributions for all contracts of mandate & Increasing \\
\hline 2015 & 2016 & $\begin{array}{c}\text { Maximum total duration and renewals of fixed-term } \\
\text { contracts }\end{array}$ & Increasing \\
\hline 2016 & 2016 & Minimum wage on contracts of mandate (civil law \\
contracts) & \\
\hline
\end{tabular}

Source: Own elaboration based on LABREF and Polish legislation.

The changes in Polish labour law introduced between the late early 2000s and the mid-2010s were minor modifications rather than substantial reforms (see Table 2). There was no change in the degree to which permanent workers are protected against individual dismissal (the relevant OECD EPL indicator has been flat and close to the OECD average). The rules on collective dismissals were loosened slightly in the early 2000s. The regulation on the number of renewals of fixed-term contracts was temporarily loosened in 2003, and was then tightened again from 2004 onwards. Before 2002, employers were allowed to renew a fixed-term contract with a given individual only twice; thereafter, the employment contract had to be converted into an open-ended contract if it was renewed immediately. A reform introduced in 2003 allowed for the unlimited renewal of fixed-term contracts; but the rule was valid only until EU accession in 2004. After Poland joined the EU, the regulations were made consistent with the EU directive on fixed-term work (1999/70/EC): i.e., employers were allowed to sign only two fixed-term contracts with a single worker, and the third FTC had to be automatically converted to an open-

\footnotetext{
${ }^{2}$ A more detailed discussion of regulations, workers' rights and employers' obligations related to each of these contract types can be found in Lewandowski and Magda (2017).
} 
ended contract if it was signed within a month of the expiration of the previous contract. ${ }^{3}$ Between 2004 and 2015 , the firing and hiring rules that applied to temporary contracts remained unchanged. A raft of reforms that tightened regulations on temporary contracts were introduced in 2016 (Table 2). However, these changes were implemented after the period of our analysis (2002-2015), ${ }^{4}$ and are not reflected in our data.

The enforcement of existing labour regulations has been an issue in Poland. According to the Chief Labour Inspectorate's (CLI) annual reports, the number of labour inspectors had held steady at around 1400 between 2002 and 2008, and then increased to around 1550 in 2001-2015. Over the same period, the number of controls per year had peaked in 2003 at 101,000, then gradually declined to 80,000 per year in 2007-2008, and rebounded to 90,000 per year in 2011-2015. Unfortunately, the statistics on the enforcement of particular rules have not been consistently reported by the CLI over time. However, the CLI reports note that the fixed-term contract conversion rule (i.e., that a third successive fixed-term contract should be converted to an open-ended contract) was often circumvented by employers by allowing a month to pass between successive contracts, or by using civil law contracts to break the continuity of the employment of an individual worker. The inspections aimed at controlling the use of civil law contracts were gradually becoming less frequent. The law states that civil law contracts may not be used to employ workers who are supervised by the employer, and who perform work in a location designated by the employer. In 2002, violations of this rule affecting 17,400 workers were detected. By 2008 , this number had fallen to 8,000 . Since 2003 , the CIL has reported both the number of inspections and the number of violations. In 2013, there were 8751 such inspections and 3313 (38\%) violations; in 2014, there were 14,028 inspections and 3525 (25\%) violations; and in 2015, there were 13,040 inspections and 3482 (27\%) violations. Because of the increase in the total number of these contracts (presented in the next subsection), the probability of inspection declined from at least $3 \%$ in 2002 to around 1\% in 2008-2015.

\subsection{Incidence of temporary employment}

Overall, Polish labour market conditions improved significantly between the early 2000s and the mid-2010s. Three factors that contributed to this improvement have been identified (World Bank, 2017). First, Poland outpaced neighbouring countries in terms of GDP growth, especially in the 2004-2015 period. Second, enhanced access to education across income groups and regions translated into a significant increase in levels of tertiary education in the workforce. Third, early retirement and retirement age reforms boosted labour supply from 2008 onwards. The rise in temporary employment occurred alongside these developments.

Between 2002 and 2015, the total number of temporary workers in Poland more than doubled, from 1.5 million to 3.5 million (Figure 1). Over this period, there were increases in both the number of workers employed under fixedterm employment contracts (by 1.5 million workers) and the number of workers employed under civil law contracts (by 460,000 workers). The growth in temporary employment in Poland - both in absolute terms and as a share of total employment - started during the recession of the early 2000s, which was characterised by unemployment rates of over $20 \%$. Temporary employment continued to grow after macroeconomic conditions improved around 2004. From that point onwards, unemployment levels declined rapidly.

\footnotetext{
${ }^{3}$ These changes led to an increase in the OECD EPL index on temporary contracts from 2005 onwards.

${ }^{4}$ At the time of writing, LFS data for 2016 were not yet available.
} 
Two stages of the temporary employment boom can be distinguished. In the first stage, between 2002 and 2008, temporary employment more than doubled; increasing by 1.7 million workers. Of these workers, 1.6 million were employed under fixed-term contracts. The number of workers employed under civil law contracts increased to a lesser extent, by 180,000 . During this period, the number of unemployed individuals declined by $65 \%$, but permanent employment rose by only $6 \%$. In the second stage, between 2008 and 2015, the total increase in temporary employment increased by just 260,000 workers. During this period, the number of workers on fixedterm contracts declined by 20,000 . However, the number of workers on civil law contracts increased by 280,000 between 2007 and 2015. Most of these temporary jobs were involuntary (Gatti et al., 2014). Young people (between the ages of 20 and 39), and people with primary, basic vocational, and secondary educational levels are overrepresented among temporary workers (Lewandowski and Magda, 2017).

During the Great Recession (2008-2012), unemployment rose and employment levels under both types of contracts flattened. By 2015, the numbers of unemployed individuals had returned to 2008 levels, but the share of workers who were in temporary employment arrangements reached a peak, and was 2.3 times higher than in 2002 (Figure 1). The number of workers with open-ended contracts increased by only $9 \%$ in 2002-2015 (by $16 \%$ between the low point in 2004 and the peak in 2015). ${ }^{5}$

Figure 1. Employment in Poland under various types of contracts, 2002-2015 (in millions)

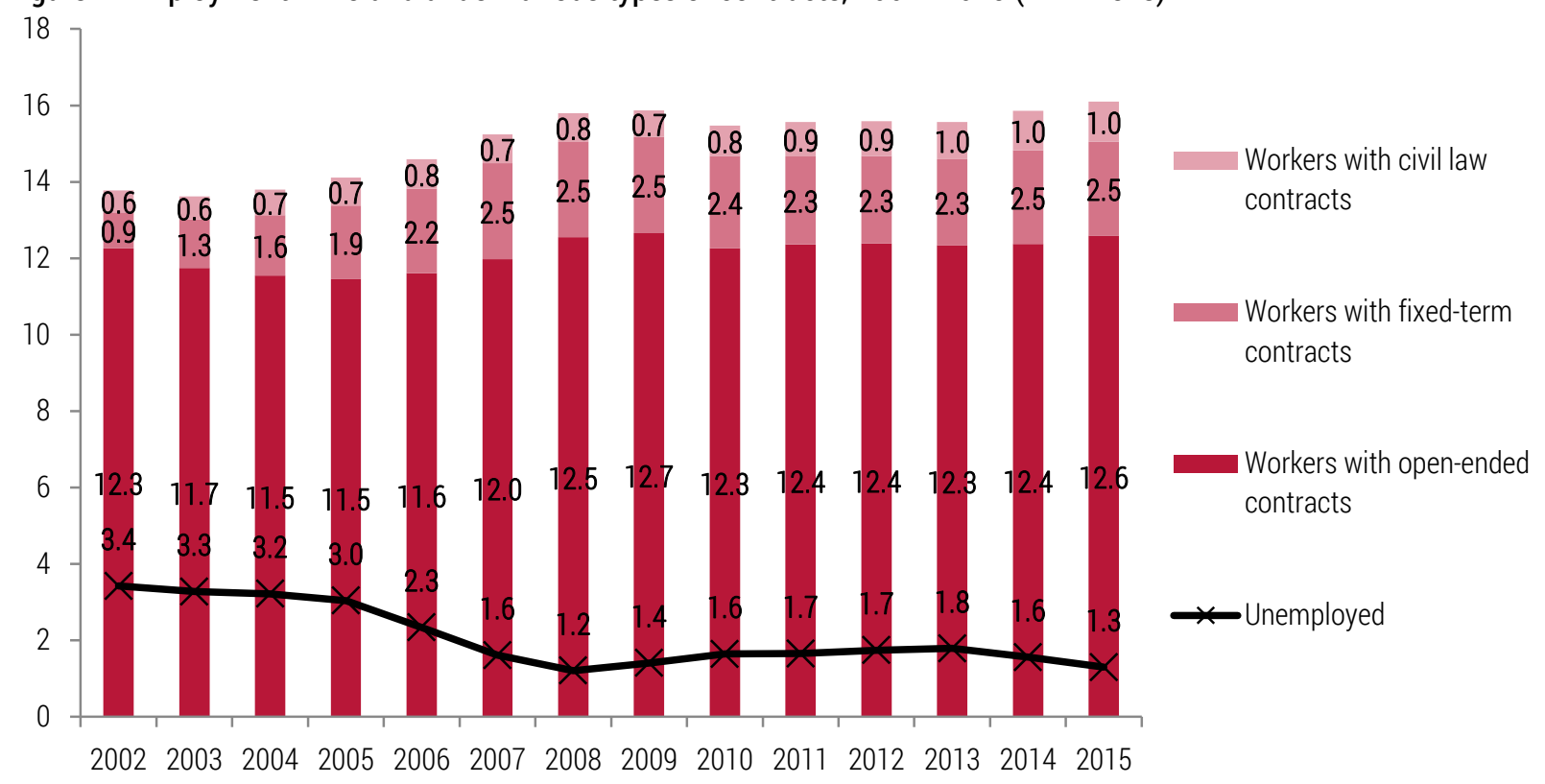

Source: Own elaboration based on LFS and Polish Ministry of Finance data.

A number of studies have shown that temporary workers lag behind permanent workers in Poland based on several economic measures. The pay penalty on temporary contracts in Poland has been estimated at around $30 \%$, if skill levels are controlled for using PIAAC data (OECD 2012). The pay penalty among involuntary temporary

\footnotetext{
${ }^{5}$ Changes in the other categories of workers were less pronounced. The numbers of self-employed individuals, including those who did and did not employ workers, increased by almost 30\% between 2002 and 2015. Finally, the secular shift away from agriculture resulted in a steady decline in the number of individual farmers (by 30\% between 2002 and 2015).
} 
workers is much larger than it is among voluntary temporary workers (Gatti et al., 2014). Compared to workers with open-ended contracts, temporary workers face a significantly higher risk of in-work poverty (Kamińska and Lewandowski, 2014) and of earning less than minimum wage (Goraus and Lewandowski, 2016). Temporary workers may also may have fewer skills acquisition, promotion, and professional development opportunities than permanent workers (Chłoń-Domińczak and Lis, 2013). However, the probability of participating in training varies significantly among temporary workers in Poland depending on their socio-demographic characteristics (Magda, 2016). Some temporary workers in Poland also face a pension penalty; Lewandowski et al. (2016) calculated that workers on civil law contracts can expect to have retirement pension levels that are $17 \%$ lower than those of similar workers with permanent employment contracts.

\subsection{Dynamics of job creation and job destruction by contract type in Poland}

The patterns of employment growth in the two sub-periods under study here (2002-2008 and 2008-2015) differed. In 2002-2008, temporary employment in Poland grew primarily because of inflows of previously jobless people. In 2009-2015, by contrast, this form of employment grew mainly because temporary workers were increasingly stuck in temporary contracts. Figure 3 presents yearly worker flow probabilities between 2002 and $2014{ }^{6}{ }^{6}$ The probability of moving from unemployment (inactivity) to employment rose from $18 \%(3 \%)$ in 2002 to $30 \%$ (5\%) in 2007 , then dropped to $26 \%(5 \%)$ in $2011-2012$, and stabilised at $29 \%(5 \%)$ thereafter. The probability of finding a permanent job after being unemployed rose from $3.4 \%$ in 2002 to $6.7 \%$ in 2007 , and then decreased to $2.7 \%$ in 2014. Meanwhile, the probability of finding a temporary job rose from $12 \%$ in 2002 to $20 \%$ in 2007 , and fluctuated between $18 \%$ and $22 \%$ thereafter.

The persistence of employment increased gradually over the entire 2002-2015 period among both permanent and temporary workers. The job separation rate ${ }^{7}$ among workers with open-ended contracts dropped from $7 \%$ in 2002 to $4.5 \%$ in 2014 , and from $30 \%$ to $17 \%$ among workers with temporary contracts. However, the average job separation rate among all workers rose from $11 \%$ in 2002 to $12 \%$ in 2007 because of composition effects (i.e., the increase in the share of temporary employment in total employment), but later declined, reaching $8 \%$ in $2015 .{ }^{8}$

The rise in employment persistence was accompanied by a decline in the number of transitions from temporary to permanent employment, especially after 2008 (Figure 2). The probability of moving from temporary to permanent employment was increasing between 2004 (15\%) and 2007 (22\%), but declined from 2009 onwards, and fell to $10 \%$ in 2015. The probability that a temporary contract worker with a tenure of up to one year would remain in the same (temporary) job a year later rose from 50\% in 2002 to $70 \%$ in 2015 , whereas the probability that such a worker would move to a permanent job dropped from $16 \%$ in 2002 to $7 \%$ in 2015 . Among temporary workers with at least one year of tenure on a temporary contract, the probability of remaining in the same temporary contract rose from $62 \%$ in 2002 to $77 \%$ in 2015 , whereas the probability of moving to permanent

\footnotetext{
${ }^{6}$ Dates used here indicate the initial year of each flow period; thus, 2002 represents flows between 2002 and 2003, 2014 represents flows between 2014 and 2015, and so on.

${ }^{7}$ The job separation rate takes into account employment to joblessness and job-to-job flows.

${ }^{8}$ Changes in separation rates translated into an increase in the expected duration of tenure: the expected duration rose from 10 years in 2002 to 12.5 years in 2015 for all contract types; from 14 years in 2002 to 22 years in 2015 for permanent contracts; and from 3.5 years in 2002 to six years in 2015 for temporary contracts.
} 
employment declined from $14 \%$ in 2002 to $11 \%$ in 2015 . At the same time, worker flows from permanent to temporary jobs increased from $1 \%$ in 2004 to $2 \%$ in 2011 , and later declined to $1.4 \%$ in 2014 .

Figure 2. Labour market flows in Poland, 2002-2014, people aged 15-64 (in \%)

Temporary workers
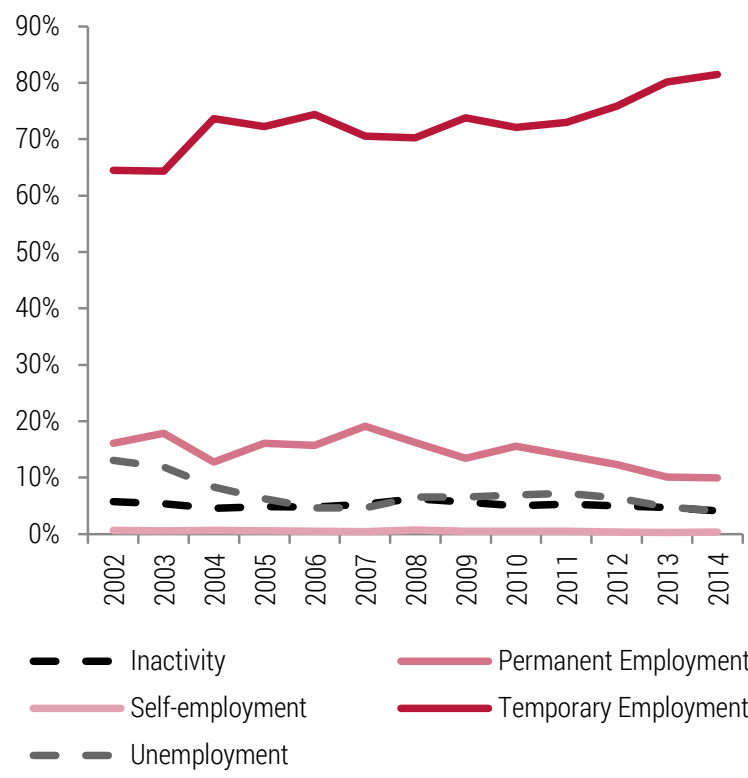

Unemployed

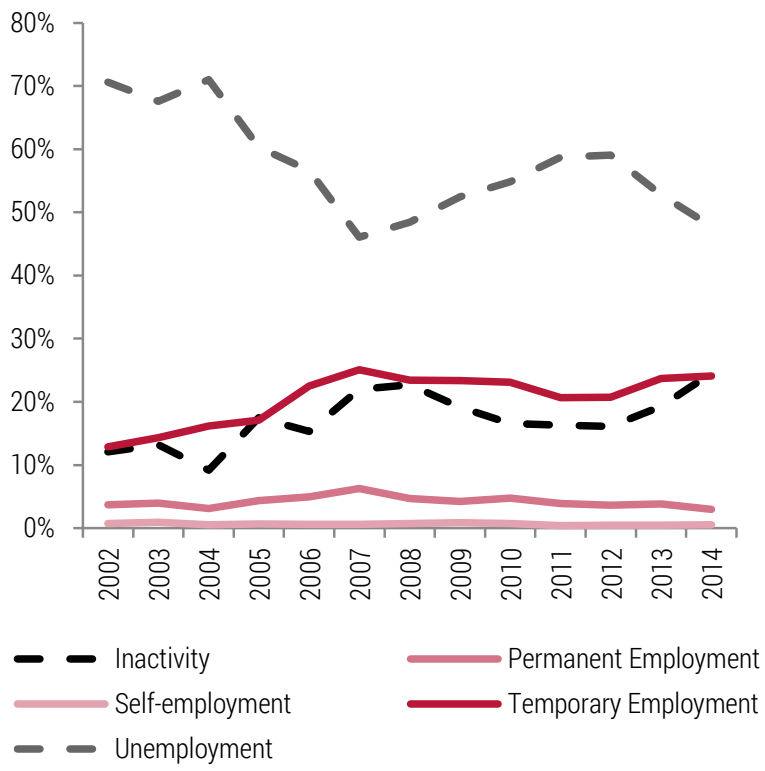

Permanent workers

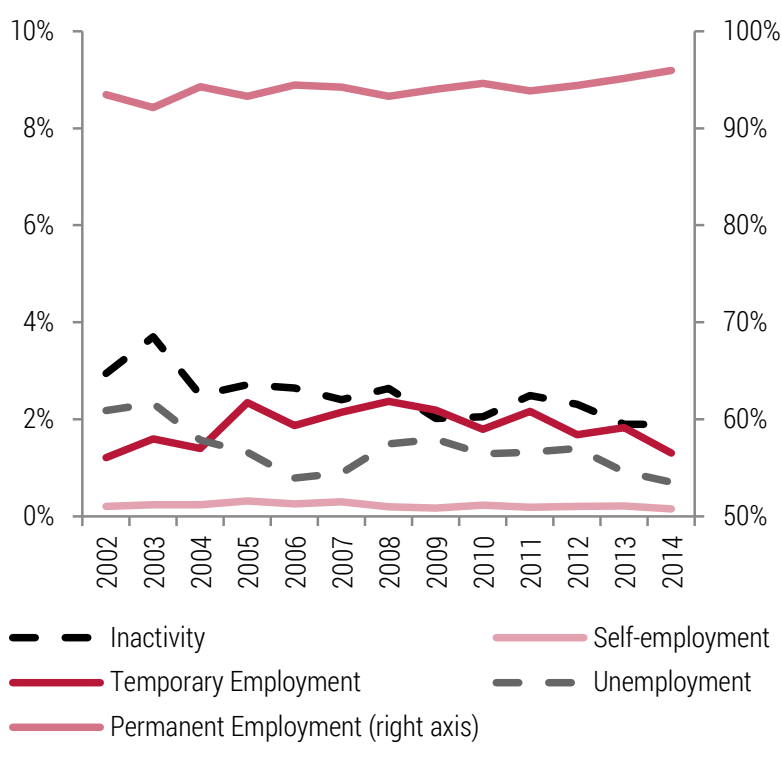

Inactive individuals

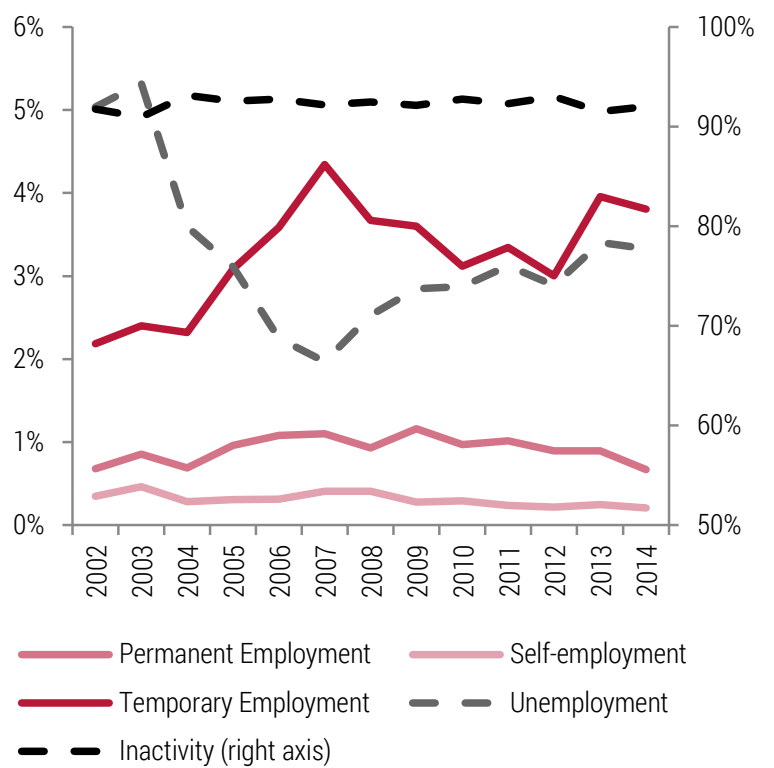

Note: Yearly flows.

Source: Own calculations based on LFS data.

The rise in the duration of temporary contracts, the increase in the average level of job destruction until 2008, and the decline in the probability of moving from temporary to permanent employment together suggest that permanent contracts were replaced by temporary contracts, at least to some extent. In order to quantify the contribution of particular transitions to the dynamics of employment, for each year between 2002-2015 we have 
calculated the yearly transition matrix between inactivity, unemployment, temporary employment with a tenure up to one year; temporary employment with a tenure of at least one year; permanent employment with a tenure up to one year; permanent employment with a tenure at least one year; self-employment; and family farming.

In the next step, we compute the numbers of individuals in total employment, in temporary employment, and in permanent employment in 2002-2015, assuming that selected transition probabilities would have changed as recorded, while the other probabilities would have remained at the 2002 level.

Formally, the number of individuals in a state $i$ in year $t\left(t>t_{0}\right)$ is given by:

$$
x_{t+1}^{i}=\sum_{j \in J} x_{t}^{j} p_{t-1, t}^{j, i}
$$

where $p_{t-1, t}^{j, i}$ is the probability of a transition from state $j$ to $i$. The hypothetical evolution of state $i$ due to only observed changes in outflow probabilities from state $k$ only is given by the formula:

$$
\widehat{x_{t+1}^{l}}=\sum_{j \neq k} \widehat{x_{t}^{J}} p_{t_{0}-1, t_{1}}^{j, i}+\widehat{x_{t}^{k}} p_{t-1, t}^{k, i}
$$

Where the initial values $\left(x_{t_{0}}^{i}\right)$ are calculated for 2002. In a matrix notation, this means that only a selected row of the transition matrix is updated. The difference between such a hypothetical evolution and an evolution calculated under the assumption that the transition matrix is fixed at 2002 values quantifies the contribution of changes in particular outflow probabilities to the number of people in a particular state. For example, keeping all transition probabilities constant except for the probabilities of outflows from unemployment and inactivity allows us to assess the contribution of job creation (outflows from unemployment and inactivity) to changes in permanent, temporary, and total employment. Figure 3 presents the contribution of (i) job creation, (ii) the duration of selected types of contracts (defined as a probability of remaining in the same state), and (iii) initial transition probabilities.

The decomposition confirms that the two sub-periods (2002-2008 and 2009-2015) differed greatly in terms of job creation. In 2002-2008, job creation was the dominant factor in the growth in both permanent and temporary employment. In 2009-2015, by contrast, inflows from joblessness were stable, and the decline in the destruction of jobs (both temporary and permanent) was the main factor in employment growth.

The decomposition further suggests that the substitution of some types of contracts with other types of contracts was an important feature of the growth in temporary employment in Poland. The increasing duration of temporary contracts contributed negatively to the number of permanent jobs. Overall, out of the 2.7 million net jobs that were added between 2002 and 2015, almost one million can be attributed to the rise in outflows from unemployment and inactivity, 740,000 can be attributed to the decline in the destruction of permanent jobs, and 687,000 can be attributed to the increase in the duration of temporary contracts. 
Figure 3. The contribution of changes in selected transition probabilities to the changes in total (top panel), permanent (medium panel) and temporary (bottom panel) employment in Poland
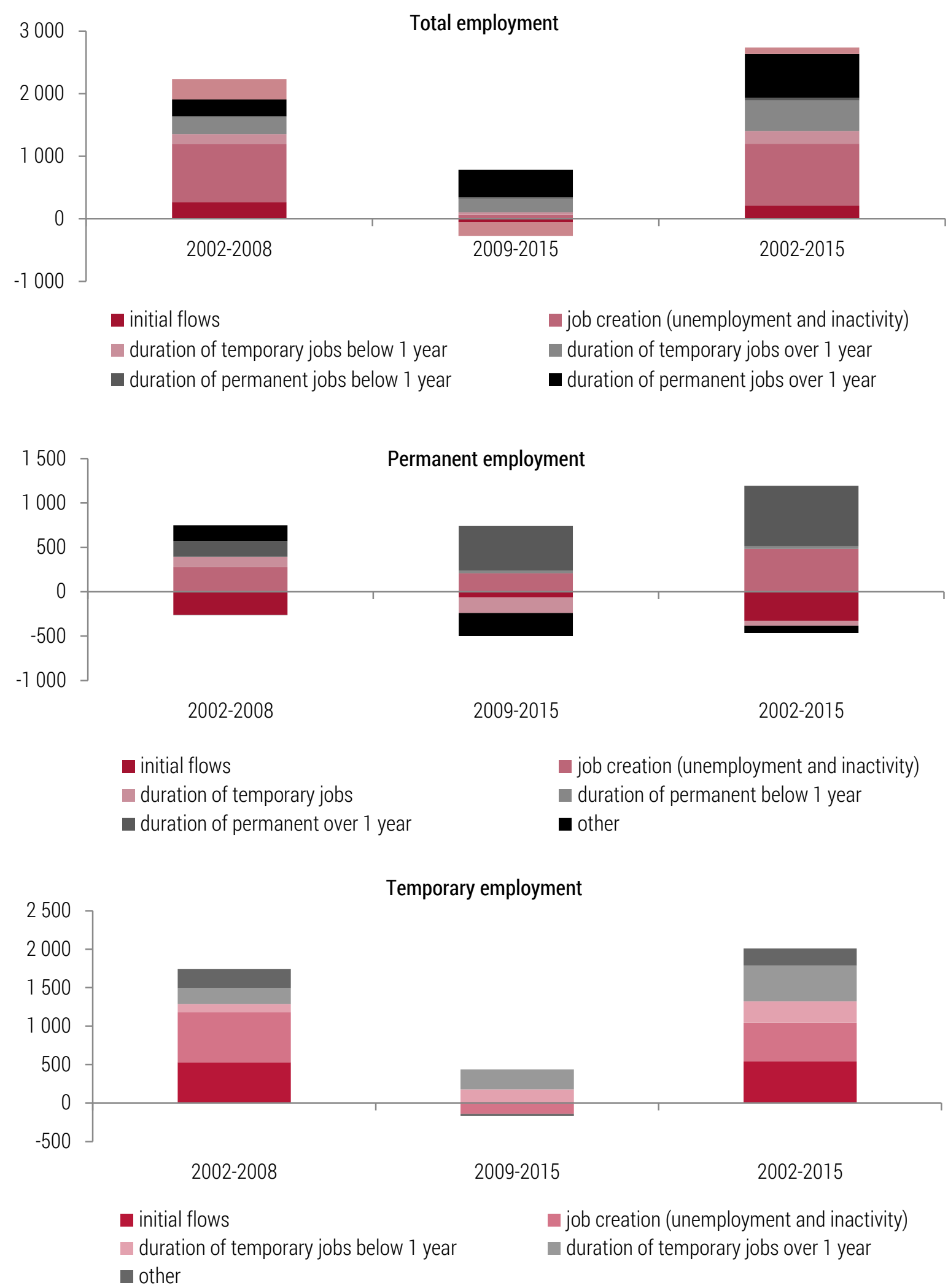

Note: The residual is calculated as a difference between the actually observed changes and the sum of all factors presented. Source: Own calculations using the LFS data. 


\section{Job quality among permanent and temporary workers in Poland}

\subsection{Definitions of job quality and data used}

The issue of job quality has been increasingly covered by the literature, but the concept of job quality is still broad, and is not uniformly defined (Hauff and Kirchner, 2014). Recent approaches to addressing this issue have expanded the traditional view that wages define job quality. Conceptualisation and measurement frameworks of non-pecuniary job quality have, for example, been developed by the ILO, the OECD, and Eurofound.

Eurofound and the ILO use an extensive list of non-pecuniary jobs characteristics, ranging from skills and training, to working conditions, to work-life balance. The Eurofound job quality measures follow the Job Quality Index developed by Muñoz de Bustillo et al. (2011), and have been elaborated by Eurofound (2012), and Hurley et al. (2013). Five dimensions of job quality are distinguished on the basis of the European Working Conditions Survey: pay, intrinsic quality of work, employment quality, health and safety, and work-life balance. The pay dimension covers both income and wage inequality. The measure of the intrinsic quality of work includes factors such as opportunities to learn new things, the repetitiveness of tasks, the ability to choose methods of work, and levels of social support. The employment quality index is based on information on training opportunities, tenure, and the type of contract. The health and safety dimension accounts for exposure to different physical and psychosocial risks at work. Finally, the work-life balance dimension includes indicators of work duration, scheduling (work at night, in the evening, on Saturday and Sunday), flexibility, and speed; and of pressure to work to tight deadlines. In the construction of the Eurofound index, all of the variables are recoded into a metric of 0-100, with zero being the least desirable outcome, and 100 being the most desirable outcome. The scores for individual variables are (in most cases) arithmetically averaged to construct indices for each of the five dimensions indicated above. The value of the Job Quality Index is obtained by geometrically averaging the five dimensions, which results in decreasing returns for the different dimensions of job quality (Muñoz de Bustillo et al., 2011).

The OECD has proposed three measures of job quality: earnings quality, labour market security, and quality of the work environment (Cazes et al., 2015). This approach follows Kalleberg et al. (2000), who defined bad jobs as jobs without health insurance and pension benefits. Unlike Eurofound, the OECD analyses each of these dimensions separately rather than constructing a composite index (Cazes et al., 2015). Earnings quality is measured in the generalised means framework under the assumption of 'moderate inequality aversion'. For the hourly wage distribution, a weight of $65 \%$ is assigned to the bottom tercile, a weight of $25 \%$ is assigned to the second tercile, and a weight of $10 \%$ is assigned to the top tercile (Cazes et al., 2015). The labour market security measure has two components. The first component is calculated as the risk of unemployment minus the unemployment insurance measure that captures both the coverage and the replacement rates of unemployment benefits / assistance. The second component accounts for labour market insecurity due to extreme low pay (defined as an absolute value of net hourly earnings of 1 US \$, PPP). The quality of the working environment (QWE) dimension 
has two components: job strain (the share of workers who face more job demands than the number of resources they have at their disposal ${ }^{9}$ ) and long (usual) working hours (more than 60 hours per week).

The measures proposed by the OECD and Eurofound are aimed at measuring job quality at the country level. Our aim is to quantify job quality among temporary and permanent workers in Poland. To this end, we have selected those job quality measures that can be adapted to subgroups of workers. Moreover, in order to analyse changes over time, we have selected measures that can be calculated using the LFS data (annual data from 2002 to 2015), and complement these measures with one measure calculated with the EWCS data (2005, 2010 and 2015).

We analyse the following dimensions of job quality (data source in brackets):

- Earnings quality (LFS) - We implement the OECD measure (Cazes et al., 2015) and calculate a weighted average of individual hourly earnings. adjusted for inflation (constant 2015 PLN). We assign a weight of 65\% to the bottom tercile, a weight of $25 \%$ to the second tercile, and a weight of $10 \%$ to the top tercile (we calculate terciles for permanent workers and temporary workers separately).

- Labour market security (LFS) - We adapt the OECD approach, and calculate the share of workers moving to unemployment in a given year. We are not able to correct this unemployment risk measure with an unemployment benefit measure because the OECD replacement rates are not available for subgroups of workers. However, we account

- Development opportunities (LFS) - We define this dimension as the share of workers who took part in training provided by their employer four weeks prior to the survey. This approach is similar to that of Muñoz de Bustillo et al. (2011), but they used information about participation in training 12 months prior to the survey. The difference in these approaches is due to differences in the survey design of the EWCS (12 months) and of the LFS (4 weeks). We do not recode the answers to 0/50/100 scores, as Muñoz de Bustillo et al. (2011) did; instead, we calculate the shares of workers participating in training.

- Job strain (EWCS) - We implement the OECD measure (Cazes et al., 2015; OECD, 2014). Two job demands (time pressure at work, physical health risk factors) and two job resources (work autonomy and learning opportunities, social support at work) are calculated for each worker. The job strain measure is defined by the share of workers who face more job demands than job resources; i.e., two demands to one or no resource, or one demand to no resource.

- Incidence of long working hours (LFS) - We define long working hours as usually working more than 50 hours per week. This approach is in line with the methodology of Eurofound and OECD. ${ }^{10}$ Long working hours are also included in the job strain measure (EWCS for 2005, 2010 and 2015), but we calculate this indicator separately using the LFS data in order to obtain annual results for the 2002-2015 period.

- Scheduling (LFS) - We follow the Eurofound approach. The questions regarding the frequency of work in the Polish LFS are consistent with those in the EWCS, and they collect information on work at night, in the evenings, on Saturdays and on Sundays. We follow Muñoz de Bustillo et al. (2011) in recoding the answers into a metric of 0-100. The answer 'never' is coded as 100 (most desirable), 'sometimes' is coded as 50, and

\footnotetext{
${ }^{9}$ Cazes et al. (2015) identified two job demands (time pressure at work and physical health factors) and two job resources (workplace relationships, and work autonomy and learning opportunities). A worker experiences job strain when he or she has more job demands than job resources.

${ }^{10}$ OECD uses 60 hours per week as an additional threshold, but because the incidence of usual weekly working hours above 60 is negligible in Poland, we decided not to use this threshold.
} 
'usually' is coded as zero (least desirable). The scores of each aspect of scheduling are then averaged arithmetically to obtain the scheduling measure. This measure is also a sub-dimension of the job strain measure, but we calculate this indicator separately using the LFS data in order to obtain annual results for the 2002-2015 period.

Table 3 shows how our job quality measures correspond to the measures used by Eurofound and the OECD.

Table 3. The dimensions of job quality

\begin{tabular}{|c|c|c|}
\hline Dimension (unit) & $\begin{array}{l}\text { Corresponding dimension in the } \\
\text { Eurofound methodology (unit) }\end{array}$ & $\begin{array}{l}\text { Corresponding dimension in the OECD } \\
\text { methodology (unit) }\end{array}$ \\
\hline $\begin{array}{l}\text { Earnings quality } \\
\qquad(\mathrm{PLN})\end{array}$ & $\begin{array}{c}\text { Pay } \\
\text { (scale } 0-100)\end{array}$ & $\begin{array}{l}\text { Earnings quality } \\
\text { (US dollar PPP) }\end{array}$ \\
\hline $\begin{array}{l}\text { Labour market security } \\
\qquad(\%)\end{array}$ & - & Labour market security \\
\hline $\begin{array}{l}\text { Development opportunities } \\
\text { (\% of total) }\end{array}$ & $\begin{array}{l}\text { Development opportunities - } \\
\text { sub-index of employment quality } \\
\text { (scale } 0-100)\end{array}$ & $\begin{array}{c}\text { Work autonomy and learning } \\
\text { opportunities - sub-index of job strain } \\
\text { (\% of total) }\end{array}$ \\
\hline $\begin{array}{l}\text { Job strain } \\
\text { (\% of total) }\end{array}$ & $\begin{array}{l}\text { Intrinsic quality of work; workplace } \\
\text { risks; working time and work-life } \\
\text { balance } \\
\text { (scale } 0-100)\end{array}$ & $\begin{array}{l}\text { Job strain } \\
\text { (\% of total) }\end{array}$ \\
\hline $\begin{array}{c}\text { Incidence of long working hours } \\
\text { (usually more than } 50 \text { hours per week) } \\
\text { (\% of total) }\end{array}$ & $\begin{array}{c}\text { Duration - sub-index of working time } \\
\text { and work-life balance } \\
\text { (scale 0-100) }\end{array}$ & $\begin{array}{c}\text { Work autonomy and learning } \\
\text { opportunities - sub-index of job strain } \\
\text { (\% of total) }\end{array}$ \\
\hline $\begin{array}{l}\text { Scheduling } \\
\text { (scale 0-100) }\end{array}$ & $\begin{array}{l}\text { Scheduling - sub-index of working time } \\
\text { and work-life balance } \\
\text { (scale 0-100) }\end{array}$ & - \\
\hline
\end{tabular}

Source: Own elaboration based on Eurofound (Muñoz de Bustillo et al., 2011) OECD (Cazes et al., 2015) and LFS data.

Unlike the EWCS, the Polish LFS lacks questions on autonomy, social support, physical risks, and work intensity. Thus, we are unable to calculate scores for the intrinsic quality of work and the workplace risks dimensions from the Eurofound methodology. Moreover, we do not use the OECD Labour Market Insecurity Due to Extreme LowPay component because the $\$ 1$ earnings threshold is not relevant for Poland. ${ }^{11}$

\footnotetext{
${ }^{11}$ An additional component that is relevant for Poland could account for future old-age pension entitlements. Since Poland has a defined contribution pension system, lower or unpaid contributions could lead to lower pensions in the future. However, the L:FS data do not allow calculating the pension contributions of workers.
} 


\subsection{Job quality gap between temporary and permanent workers in Poland}

Between 2002 and 2015, job quality among temporary workers was systematically lower than among permanent workers in Poland. Differences in job quality between these two groups of workers were found for all the dimensions of job quality that we analysed and presented in Figure 4.

Earnings quality, job security, and scheduling quality were the three most important dimensions of the job quality gap. The quality of (hourly) earnings was $23 \%$ to $28 \%$ lower among temporary workers than among permanent workers. Job security was also noticeably lower among temporary workers than among permanent workers over the entire period studied. The shares of temporary workers who transitioned to unemployment were 4.5-6 times higher than the corresponding shares of permanent workers (yearly flows).

The quality of work scheduling was the third main dimension of difference between temporary and permanent workers. Although the average gap over the 2002-2015 period was modest, the quality of job scheduling was the only dimension for which an initial reduction in the size of the gap (between 2004 and 2008) was completely reversed, and had reached its widest point in 2015. Moreover, the gap in the dimension of job strain, which is a broader measure that accounts for work scheduling (and is calculated with EWCS data instead of LFS data), was also widest in 2015. Meanwhile, the incidence of long hours was higher among temporary workers than among permanent workers (by $1.5 \mathrm{pp}$, on average).

Having access to development opportunities was the least important dimension of the job quality gap. As the share of workers who had taken part in training organised by their employer four weeks prior to the interview was very low for both groups of workers (between 1\% and 2.5\%), the differences between the permanent and the temporary workers were also tiny. In Poland, life-long learning is under-developed (Sondergaard et al., 2012). Thus, while this dimension can contribute to overall job quality, we do not consider it to be relevant to the differences between temporary and permanent workers.

Among temporary workers, most of the dimensions of job quality improved between 2002 and 2015, except for development opportunities and job strain. Among both groups of workers, earnings quality and job security improved substantially between 2002 and 2015, which may be related to the overall improvement in labour market conditions. While the differences in earnings quality and job security between the two groups declined, they still remained substantial. The earnings quality measure for temporary workers lagged behind the earnings quality measure for permanent workers by seven years. The lowest job insecurity measure recorded among temporary workers (4.1\% flows to unemployment in 2014) was nearly twice as high as the highest job insecurity measure recorded among permanent workers (2.3\% flows to unemployment in 2003).

The quality of working time also improved over time. The incidence of long hours declined for both groups, from around $7 \%$ in 2002 to less than $4 \%$ in 2015 among temporary workers, and from around $5 \%$ in 2002 to $2.5 \%$ in 2015 among permanent workers. Thus, the gap between these two groups was halved. The quality of scheduling also improved for both groups, but virtually all of the progress made occurred between 2002 and 2010. Moreover, unlike the incidence of long working hours, the gap between temporary and permanent workers in the quality of scheduling widened noticeably.

Job strain was the only dimension for which the trends among permanent and temporary workers were diverging, especially between 2010 and 2015. Temporary workers were increasingly affected by job strain, while the opposite trend could be observed among permanent workers. 
Figure 4. Job quality among permanent and temporary workers in Poland, 2002-2015

Earnings quality (PLN, constant prices)*

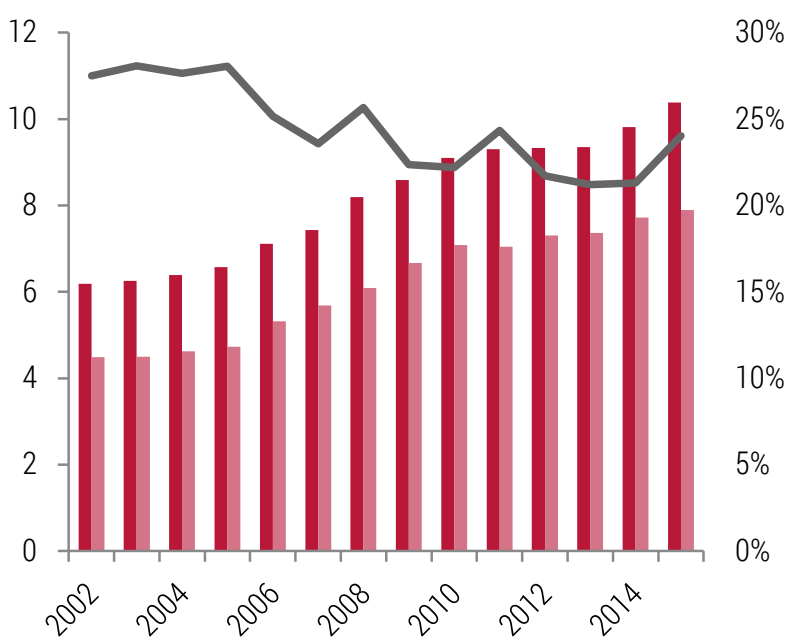

Development opportunities (\% of workers)

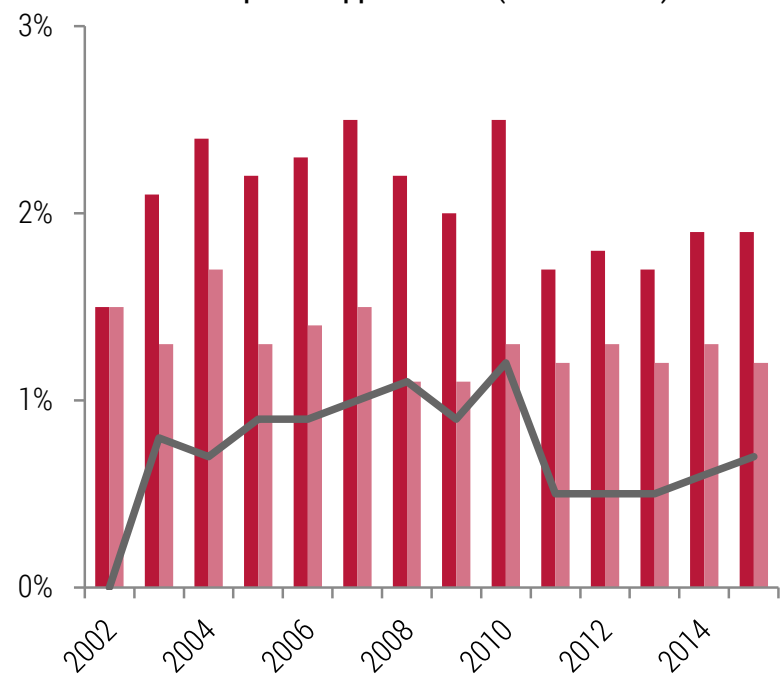

Incidence of long working hours (\% of workers)

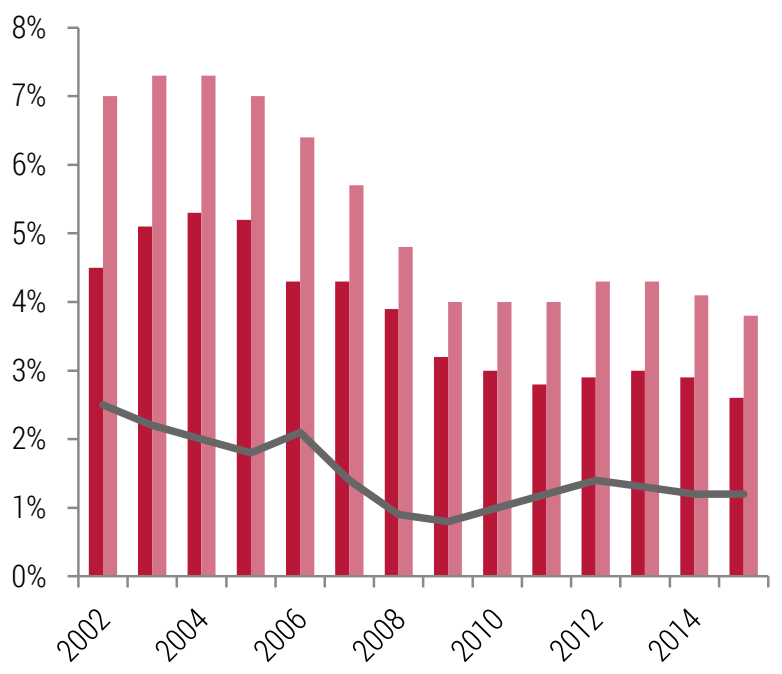

Job security
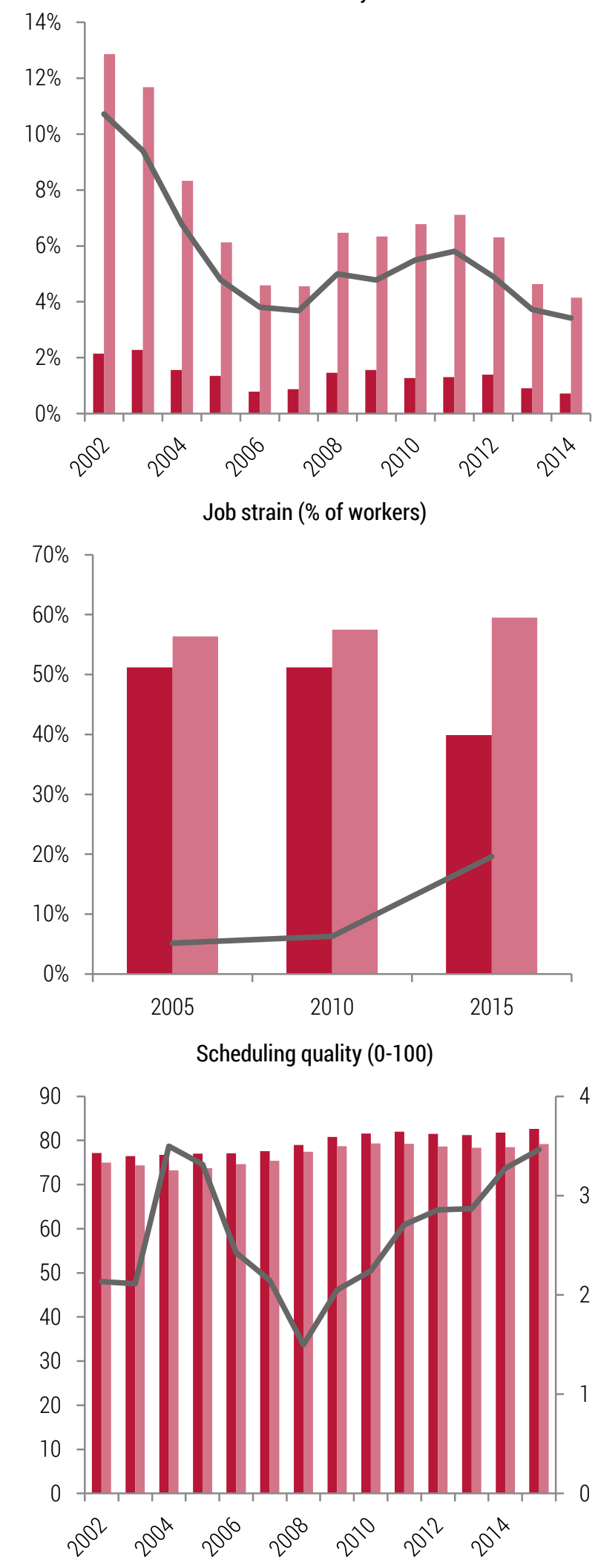

Permanent workers

Temporary workers

Difference

Note: Difference in earnings quality is expressed as a share of earnings quality indicator among permanent workers.

Source: Own calculations based on LFS and EWCS (job strain) data. 
The improvement in job quality was temporarily halted during the Great Recession, but it continued in the period that followed (Figure 4). This trend was particularly visible for earnings quality (improvement stalled in 20102014), job security (declined between 2007 and 2011, especially among temporary workers who bore the brunt of the increase in job separations), and the quality of working time (the incidence of long hours flattened among permanent workers, but increased among temporary workers between 2009 and 2013). For scheduling quality, a post-slowdown rebound was barely visible; after 2010, there were no more gains in scheduling quality for temporary workers, and the gap between temporary and permanent workers widened.

While overall job quality improved across all dimensions between 2002 and 2015, the rising incidence of temporary employment hindered this otherwise positive trend. The shift-share decomposition of job quality changes shows that the within-group effect (the change that would happen if the structure of employment remained at the 2002 level, but job quality among permanent and temporary workers changed as reported) was the main driver of the increase in job quality. However, at least $90 \%$ of this within-group effect in every measure except job security can be attributed to increasing job quality among permanent workers. For job security, the number in question is $70 \%$. The contribution of the rising share of temporary employment (the between-group effect) to the changes in job quality was most pronounced in the case of job security - it nearly cancelled out the within-group progress (Table 4) - and the incidence of long working hours.

Table 4. Shift-share decomposition of job quality changes in Poland between 2002 and 2015

\begin{tabular}{|c|c|c|c|c|c|c|}
\hline Type of effect & $\begin{array}{c}\text { Earnings } \\
\text { quality }\end{array}$ & $\begin{array}{c}\text { Job security } \\
\text { (in pp.) }\end{array}$ & $\begin{array}{c}\text { Development } \\
\text { opportunities } \\
\text { (in pp.) }\end{array}$ & $\begin{array}{c}\text { Job strain } \\
\text { (in pp.) }\end{array}$ & $\begin{array}{c}\text { Incidence of } \\
\text { long working } \\
\text { hours (in pp.) }\end{array}$ & $\begin{array}{c}\text { Scheduling } \\
\text { quality }\end{array}$ \\
\hline Within-group & 4.1 & 1.9 & 0.4 & -8.2 & -2.1 & 5.3 \\
\hline Between-group & -0.3 & -1.6 & 0.0 & 0.1 & 0.4 & -0.3 \\
\hline Interaction & -0.1 & 1.1 & -0.1 & 0.5 & -0.2 & -0.2 \\
\hline Total change & 3.8 & 1.6 & 0.3 & -7.6 & -1.9 & 4.8 \\
\hline
\end{tabular}

Note: 2002-2014 in the case of job security. 2005-2015 in the case of job strain.

Source: Own calculations based on LFS and EWCS data.

Job quality was found to be lower among temporary workers than among permanent workers, even if the impact of other personal and workplace characteristics was controlled for. Table 5 presents the effects of temporary contracts on hourly earnings (estimated in the Mincerian wage regression) and the odds ratios for temporary contract dummies estimated in the logit regressions on the incidence of low job quality in particular dimensions. ${ }^{12}$ In all regressions, we controlled for a range of personal and workplace characteristics: gender, age, education (five levels), occupation (nine one-digit ISCO groups), sector (16 NACE sectors), firm size, firm ownership (private vs. state), and NUTS2 region. To save space, we do not present all of the estimated parameters. $^{13}$

\footnotetext{
${ }^{12}$ We assume that scheduling quality is low if the value of the scheduling measure for an individual is up to 50 . On average between 2002 and $2015,19.6 \%$ of all workers were identified as being subject to low scheduling quality.

${ }^{13}$ All estimation results are available upon request.
} 
Table 5. The effects of temporary contracts on wages (parameter estimated in the Mincerian wage regression) and the incidence of low job quality (odds ratios from the logit regressions for particular dimensions)

\begin{tabular}{|c|c|c|c|c|c|c|c|c|c|c|c|c|c|c|}
\hline Dimension & 2002 & 2003 & 2004 & 2005 & 2006 & 2007 & 2008 & 2009 & 2010 & 2011 & 2012 & 2013 & 2014 & 2015 \\
\hline $\begin{array}{c}\text { Hourly } \\
\text { earnings* }\end{array}$ & $-0.18 * \star \star$ & $-0.18^{\star \star \star}$ & $-0.15^{\star \star \star}$ & $-0.15^{\star \star \star}$ & 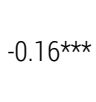 & $-0.15^{\star \star \star}$ & 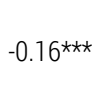 & 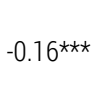 & $-0.15^{\star \star \star}$ & $-0.16^{\star \star \star}$ & $-0.15^{\star \star \star}$ & $-0.15^{\star \star \star}$ & $-0.13^{\star \star \star}$ & 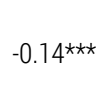 \\
\hline Job loss & $4.27 \star \star \star$ & $3.38^{\star \star \star}$ & $3.40^{\star \star \star}$ & $3.31^{\star \star \star}$ & $4.16^{\star \star \star}$ & $3.85^{\star \star \star}$ & $3.10 \star \star \star$ & $2.98^{\star \star \star}$ & $3.84^{\star \star \star}$ & $3.98^{\star \star \star}$ & $3.07 \star \star \star \star$ & $3.60^{\star \star \star}$ & 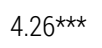 & na \\
\hline Training & 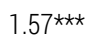 & 0.96 & $1.28^{\star \star}$ & 1.02 & 1.06 & 1.01 & 0.90 & 1.00 & 0.94 & $1.24 \star \star$ & $1.27 \star \star \star$ & $1.27^{\star \star \star}$ & $1.17 \star \star \star$ & 0.97 \\
\hline Job strain & na & na & na & 1.03 & na & na & na & na & 1.07 & na & na & na & na & $2.26^{\star * *}$ \\
\hline $\begin{array}{c}\text { Incidence } \\
\text { of long } \\
\text { working } \\
\text { hours }\end{array}$ & $1.19 \star \star$ & $1.12^{\star}$ & 1.11 & 1.03 & $1.13^{\star \star}$ & 1.09 & 1.08 & $1.13^{\star \star}$ & $1.12^{\star \star}$ & $1.18^{\star \star \star}$ & $1.23^{\star \star \star}$ & 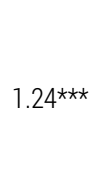 & $1.16^{\star}$ & $1.20 \star \star \star$ \\
\hline $\begin{array}{c}\text { Low } \\
\text { scheduling } \\
\text { quality }\end{array}$ & 1.02 & 1.00 & 1.08 & 1.04 & 1.01 & 1.02 & 1.04 & $1.09 \star \star$ & $1.09 \star \star \star$ & $1.06^{\star}$ & $1.08^{\star \star \star}$ & 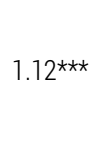 & 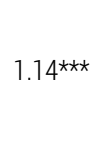 & $1.09 *$ \\
\hline
\end{tabular}

Note: *Parameter estimates from the Mincerian wage regression. Odds ratios are estimated in logit models for other measures. Yearspecific regressions on the sample of dependent workers. Scheduling quality is defined as low if the value of the scheduling measure for an individual is up to 50. Explanatory variables include the following: gender, age, education (five levels), occupation (nine 1-digit ISCO groups), sector (16 NACE sectors), firm size, firm ownership (private vs. state controlled), NUTS2 region. Standard errors clustered at the NUTS2 level.

Source: Own estimations on LFS and EWCS data.

We found that workers with temporary contracts had significantly lower (hourly) earnings and significantly higher risks of job loss than similar workers with permanent contracts over the entire period studied. Especially after 2009, temporary workers also faced significantly higher risks of working long hours, and had significantly lower levels of job scheduling quality. For job strain, we found no significant effects of temporary contracts in 2005 and 2010, but a strong and positive effect in 2015 (EWCS data); which confirms that job strain risk diverged between temporary and permanent workers. Surprisingly, temporary workers had higher probabilities of participating in training than permanent workers with comparable characteristics in six out of 14 years studied. This finding may be related to the lower levels of experience among temporary workers. However, since only very small shares of both groups of workers had participated in training, we think that this particular result does not affect our overall conclusion that job quality was lower among temporary workers.

\subsection{Job security vs. other dimensions of job quality}

The OECD measure of job security adjusts the risks of job loss according to the replacement rates of unemployment benefits. We were not able to apply this approach directly because the replacement rates of unemployment benefits are not available for subgroups of workers. However, here we present the results of our analysis of the extent to which temporary and permanent workers who moved to unemployment were covered by unemployment benefits, and of the interactions between job security and other dimensions of job quality. 
The gap in job security between temporary and permanent workers becomes even larger if unemployment benefit coverage is taken into account. ${ }^{14}$ Between 2002 and 2014, nearly two-thirds of workers with permanent contracts who moved to unemployment (yearly flows) were claiming unemployment benefits. Among workers with temporary contracts, benefits were claimed by slightly more than one-third of individuals who moved to unemployment. As the overall flows to unemployment were much larger among temporary workers than among permanent workers, the share of unemployed individuals who lacked unemployment benefits within one year of becoming unemployed was almost nine times greater among temporary workers than among permanent workers (on average in 2002-2014, Figure 5).

Figure 5 . The unemployment benefit status of permanent workers and temporary workers moving to unemployment in Poland between 2002 and 2014
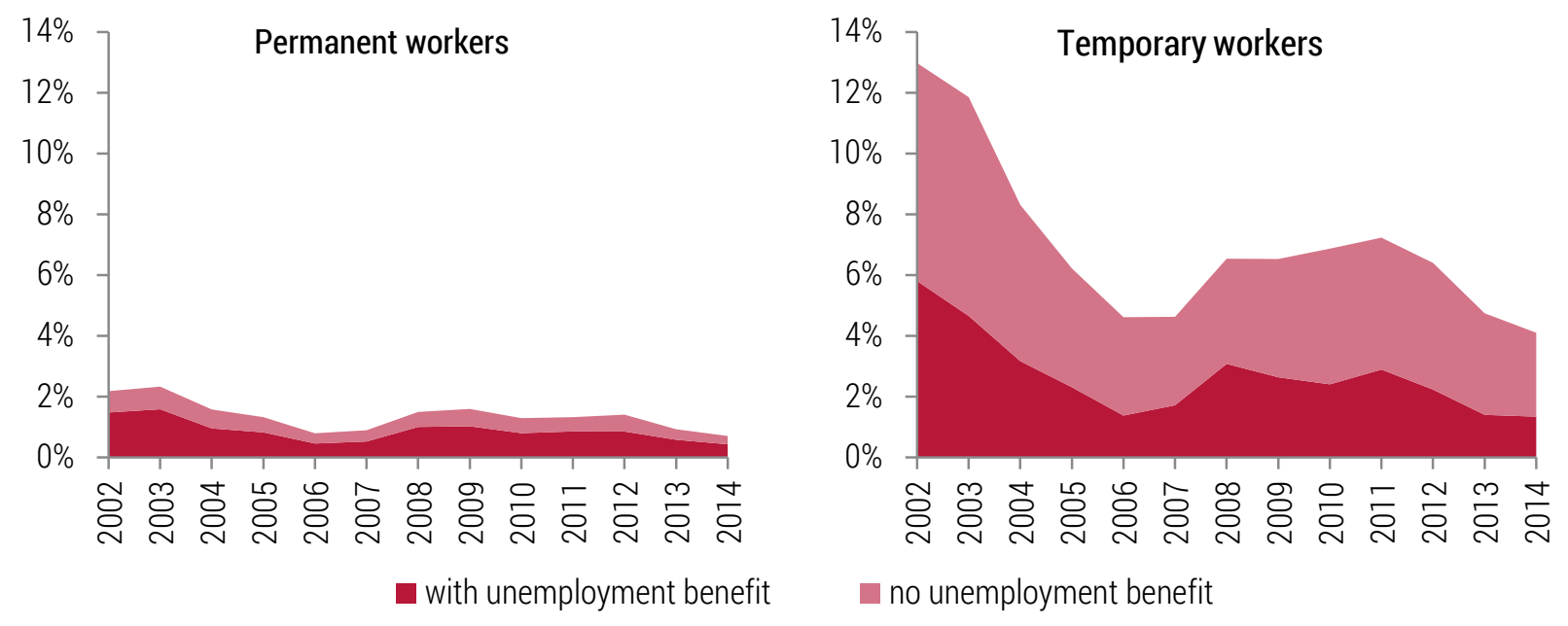

Source: Own calculations based on LFS data.

Workers with low job quality, particularly in terms of work scheduling and training, also tended to have low job security. In order to analyse the interplay between these dimensions of job quality, we estimated multinomial logit models on yearly labour market flows of temporary workers to permanent employment or unemployment, and on yearly transitions of permanent workers to temporary employment or unemployment. In both sets of models, workers who remained in the same type of job constituted the reference groups. We controlled for the same personal and workplace characteristics as in the regressions presented in Table 5, and additionally included three dummy variables on job quality: participation in training (high job quality), long working hours, and low scheduling quality (scheduling measure below 50). Table 6 presents the odds ratios for these three dummies.

We found that temporary workers who participated in training were more likely to move to permanent jobs, especially after 2010; while permanent workers who participated in training were less likely to become unemployed. Temporary workers with low scheduling quality were less likely to move out of temporary jobs, both to permanent jobs and to unemployment; this result confirms our earlier finding that the relationship between

\footnotetext{
${ }^{14}$ To qualify for unemployment benefits in Poland, an individual has to have been employed for at least one year in the 18 months before losing a job, have earned at least the minimum wage during this period, and have registered with the public employment services. In principle, benefits are paid for six months, although members of certain groups may be eligible receive benefits for 12 months, such as unemployed individuals living in districts (NUTS4) with an unemployment rate that is $150 \%$ higher than the country's overall unemployment rate, and individuals aged $50+$ who have worked a minimum of 20 years.
} 
temporary employment and low scheduling quality has built up over time. Among permanent workers, there was no significant correlation between low scheduling quality and labour market flows. Long working hours were not significantly related to labour market transitions in either group of workers.

Table 6. The relationship between selected job quality measures and labour market flows of temporary and permanent workers (odds ratios from multinomial logit regressions)

\begin{tabular}{|c|c|c|c|c|c|c|c|c|c|c|c|c|c|}
\hline $\begin{array}{c}\text { Dimension of job } \\
\text { quality }\end{array}$ & 2002 & 2003 & 2004 & 2005 & 2006 & 2007 & 2008 & 2009 & 2010 & 2011 & 2012 & 2013 & 2014 \\
\hline \multicolumn{14}{|c|}{ Temporary workers } \\
\hline \multicolumn{14}{|c|}{ Flows to permanent employment } \\
\hline Training & 0.84 & 1.12 & $1.68 *$ & 1.43 & 0.61 & 0.95 & 1.27 & 1.14 & $1.33^{\star *}$ & $1.96 * \star \star$ & $1.41^{\star \star \star}$ & $1.88^{* \star *}$ & 0.83 \\
\hline $\begin{array}{l}\text { Long working } \\
\text { hours }\end{array}$ & 1.35 & 1.00 & 1.19 & 1.08 & 1.01 & 0.94 & 1.21 & 0.92 & $0.72^{\star}$ & 1.16 & 1.14 & 0.87 & 0.84 \\
\hline $\begin{array}{l}\text { Low scheduling } \\
\text { quality }\end{array}$ & 0.91 & $0.72^{\star \star \star}$ & 1.02 & 0.96 & 0.85 & 0.99 & $0.71^{\star \star \star}$ & $0.75^{\star \star}$ & 1.07 & 0.93 & $0.87^{\star}$ & $0.73^{\star \star \star}$ & $0.80^{\star}$ \\
\hline \multicolumn{14}{|c|}{ Flows to unemployment } \\
\hline Training & 0.45 & 1.27 & 0.90 & 1.69 & 0.80 & 0.62 & 0.63 & 0.86 & $0.60 \star \star$ & 1.20 & 0.61 & 0.77 & 1.37 \\
\hline $\begin{array}{c}\text { Long working } \\
\text { hours }\end{array}$ & $1.43^{\star}$ & 1.18 & 1.10 & 1.11 & 0.84 & 0.93 & 0.99 & 0.84 & 0.76 & 1.03 & 1.16 & 0.93 & 1.04 \\
\hline $\begin{array}{c}\text { Low scheduling } \\
\text { quality }\end{array}$ & 0.93 & $0.77^{\star \star}$ & $0.81^{\star \star}$ & $0.81^{\star \star}$ & $0.71^{\star \star}$ & 0.90 & 0.82 & 0.81 & $0.76^{\star \star \star}$ & 0.99 & $0.63^{\star \star \star}$ & $0.76^{\star \star}$ & 0.85 \\
\hline \multicolumn{14}{|c|}{ Permanent workers } \\
\hline \multicolumn{14}{|c|}{ Flows to temporary employment } \\
\hline Training & 0.26 & $0.17 \star \star$ & 0.52 & 0.64 & 1.17 & 0.95 & $1.74^{\star}$ & 1.15 & 0.70 & 0.75 & 0.96 & 0.72 & 1.21 \\
\hline $\begin{array}{l}\text { Long working } \\
\text { hours }\end{array}$ & $1.84^{\star \star}$ & 1.11 & 0.94 & 1.27 & 1.53 & 1.23 & 0.83 & 1.39 & 1.28 & $1.59 \star *$ & 1.09 & 0.83 & 0.69 \\
\hline $\begin{array}{c}\text { Low scheduling } \\
\text { quality }\end{array}$ & 1.18 & 1.29 & 1.32 & 0.73 & 0.90 & 0.98 & 0.86 & 0.90 & 0.91 & 0.99 & 1.00 & 1.17 & 1.19 \\
\hline \multicolumn{14}{|c|}{ Flows to unemployment } \\
\hline Training & 0.91 & 0.42 & $0.18 \star \star \star$ & 1.01 & 0.72 & $0.47^{*}$ & $0.45^{\star}$ & $0.54^{\star}$ & 1.01 & 0.77 & $0.68^{\star}$ & $0.53^{\star \star}$ & 1.06 \\
\hline $\begin{array}{l}\text { Long working } \\
\text { hours }\end{array}$ & $1.39 \star \star$ & 1.21 & 1.26 & 0.95 & 1.23 & 1.01 & 0.73 & 1.36 & 1.01 & 0.96 & 0.96 & 0.98 & 1.24 \\
\hline $\begin{array}{l}\text { Low scheduling } \\
\text { quality }\end{array}$ & $0.81^{*}$ & 1.12 & 1.01 & 0.97 & 1.09 & 0.94 & $0.80 *$ & 0.81 & 0.84 & 1.09 & 1.02 & 1.01 & 0.79 \\
\hline
\end{tabular}

Note: Odds ratios estimated in year-specific multinomial logit regressions - reference group includes workers remaining in the same state. Yearly flows. Participation in training four weeks prior to the survey. Long working hours are defined as 50 or more per week (usually). Scheduling quality is defined as low if the value of the scheduling measure for an individual is up to 50. Other explanatory variables include: gender, age, education (five levels), occupation (nine 1-digit ISCO groups), sector (16 NACE sectors), firm size, firm ownership (private vs. state controlled), NUTS2 region. Standard errors clustered at the NUTS2 level.

Source: Own estimations on LFS data. 


\section{Possible employment effects of temporary contracts boom in Poland}

In this section, we calculate the possible range of employment creation that could have been a consequence of the lower labour costs that were made possible by the spread of temporary contracts in Poland between 2002 and 2015. We are not arguing that this employment creation was at any particular level; rather, we are only claiming that it was likely within a certain range, and calculate the lower and upper bounds of this range. The lower bound equals zero because we cannot rule out the possibility that firms using temporary contracts employed the same number of workers that they would have employed if they had used only permanent contracts. In such a case, no additional jobs were created.

To calculate the upper bound, we used a stylised labour demand model, which is presented in subsections 4.14.2. We assume that the firms that employed workers on temporary contracts had the same total wage bill as if they had employed workers only permanent contracts only. Because temporary contracts allow for lower labour costs per worker, firms can employ more workers with the same total wage bill. We account for three sources of cost differences between temporary and permanent contracts: (i) a wage penalty associated with temporary contracts (due to, for instance, the lower bargaining power of workers), (ii) a lower tax wedge due to lower social security contribution levels for temporary contracts, and (iii) lower firing costs related to the use of temporary contracts. Our stylised model does not account for dynamic, general equilibrium and open economy effects, such as an increase in international competitiveness due to lower wages. Neither we account for worker heterogeneity.

\subsection{The stylised labour demand model}

We assume that the dynamics of employment can be decomposed into two components: the first component is related to changes in the propensity to use temporary contracts (which affect the incidence of temporary contracts at the expense of the incidence of permanent contracts), while the second component is related to changes in the aggregate demand (which affect the incidence of both permanent and temporary contracts in the same manner). This allows us to calculate the counterfactual employment scenario under the assumption that the propensity to use temporary contracts did not change between 2002 and 2005, and employment changes were driven only by aggregate demand. The difference between the observed employment and the counterfactual scenario is the upper bound of possible range of employment effects of temporary contract boom in Poland.

Temporary employment $(T)$ and permanent employment $(M)$ are functions of propensity to use temporary $\operatorname{contracts}(\lambda)$ and the aggregate demand $(A D)$ :

$$
\begin{aligned}
& T=f_{T}(\lambda, A D) \\
& M=f_{M}(\lambda, A D)
\end{aligned}
$$

Under mild regularity conditions, the dynamics of employment can be decomposed into:

$$
\begin{gathered}
\frac{d T}{d t}=\frac{\overbrace{\partial T}^{a_{T}}}{\partial A D} \overbrace{\frac{d A D}{d t}}^{x}+\frac{\overbrace{\partial T}^{y_{T}}}{\partial \lambda} \frac{d \lambda}{d t} \\
\frac{d M}{d t}=\frac{\overbrace{M M}^{a_{M}}}{\partial A D} \frac{\overbrace{d A D}^{x}}{d t}+\frac{\overbrace{M}^{y_{M}}}{\partial \lambda} \frac{d \lambda}{d t}
\end{gathered}
$$


In order to identify these relationships, two economic assumptions are needed. The first assumption states that the propensity to use temporary contracts is given by (minus) the share of temporary employment in total employment in the initial period (2002), $\left(\lambda=-\frac{T}{T+M}\right)$. This assumption ensures that temporary employment is an increasing function of the propensity to use temporary contracts. The second assumption concerns job creation resulting from workers moving from permanent to temporary contracts. Replacing a permanent contract with a temporary contract enables a firm to employ more workers, as temporary contracts incur lower total labour costs. The upper bound of how many more temporary workers than permanent workers could be employed is determined by the relative difference in the labour costs incurred by both types of contracts. We assume that a firm employing temporary workers keeps its payroll constant (i.e., equal to the payroll a firm would have if it employed all workers on permanent contracts), and devotes all of the savings from using temporary contracts instead of using permanent contracts to employing more temporary workers.

Under these assumptions, we obtain the equation defining the upper bound of the net effect of temporary contracts on employment: ${ }^{15}$

$$
\frac{d \hat{E}}{d t}=\left(1-\frac{L C_{M}}{L C_{T}}\right)\left(\frac{d M}{d t}-a_{M} x\right)
$$

The upper bound of possible employment effects depends only on the changes in the number of temporary and permanent jobs. It does not depend on the actual measure of changes in the propensity to use temporary contracts $\left(\frac{d \lambda}{d t}\right)$. This results from an implicit assumption that the propensity to use temporary contracts has no effect on aggregate demand, and that it only changes the structure of employment by contract type.

\subsection{Parametrisation of the model}

In order to determine the upper bound of possible employment effects, we calculate each component of the difference in the labour costs incurred by temporary and permanent contracts $\left(\frac{L C_{M}}{L C_{T}}\right)$ : (a) the difference in the net wage (assuming equal productivity), (b) the difference in the tax wedge, and (c) the difference in the indirect costs related to dismissal, severance pay, and notice periods (Heckman and Pages-Serra, 2000; Lazear, 1993).

\section{Wage penalty (a)}

We estimated a Mincerian type regression (on the LFS data), controlling for age, gender, education, experience, occupation, economic sector, and firm size. The results indicate that the net wage penalty associated with temporary contracts was $23.3 \%$ in 2002 , and gradually declined to $14.3 \%$ in 2015 . We also employed the model of the joint determination of wages and the assignment of temporary contracts (Barnow et al., 1981). Without an additional instrument for the type of contract, the Wald test did not allow us to reject the hypothesis of the exogeneity of temporary contracts in each year. We therefore used the parameter from a basic log-level specification. This method for measuring the wage penalty related to temporary jobs is common in the literature (Boeri 2011, Cazes and de Laiglesia 2015). This parameter is probably an upper bound estimate, as we could not

\footnotetext{
${ }^{15}$ The intermediate algebraic steps are presented in the appendix.
} 
control for unobserved heterogeneity, which would have limited this penalty. ${ }^{16}$ Using the upper bound of the wage penalty is consistent with our goal of finding the upper bound of possible employment effects.

\section{Tax wedge (b)}

We used a personal income tax and social security contributions model separately for open-ended contracts, fixed-term contracts, and civil law contracts (Arak et al., 2014). Following the estimates of Lewandowski et al. (2016) on the Social Security Institution (ZUS) data, we assumed that the average social security contributions made under a civil law contract were based on $50 \%$ of the minimum wage level. We found that the differences in the total tax wedge associated with temporary and permanent contracts gradually decreased from $21 \%$ of the tax wedge on permanent contracts in 2002 to $15 \%$ of the tax wedge on permanent contracts in 2015. For each year studied, the total tax wedge on temporary contracts was calculated as the employment weighted average of the tax wedge on fixed-term contracts and civil law contracts.

\section{Firing costs (c)}

If terminated, temporary and permanent contracts are associated with different levels of pecuniary costs (advance notification cost, compensation for dismissal, seniority premium for dismissed workers, forgone wages in the period of the legal process, Heckman and Pages-Serra, 2000) and of non-pecuniary costs (the termination of permanent contract can be perceived as unfair, Mondino \& Montoya, 2000).

Heckman and Pages-Serra (2000) estimated that the pecuniary costs of firing a permanent worker with 10 years of tenure ranged from zero in the US, to $34.5 \%$ of yearly wages in Portugal (the highest level in Europe), to $40 \%$ of yearly wages in Bolivia. ${ }^{17}$ Their estimate for Poland was $10 \%$ of yearly wages in the late 1990 s. As was shown in Section 2, since the late 1990s in Poland, there have been no substantial reforms of labour laws, and employment protection in particular has not been strengthened. The Heckman and Pages-Serra (2000) estimate can, therefore, be used as a proxy for the regulation costs associated with open-ended contracts in Poland. In our calculation of the upper bound of the potential employment effects of temporary employment boom, we assume that the firing costs associated with permanent contracts are equal to $10 \%$ of yearly earnings.

\subsection{The possible range of the employment effects of the boom in temporary contracts}

We found that between $0 \%$ and 19\% of the increase in net dependent employment between 2002 (9.9 million) and 2015 (12.6 million) can be attributed to job creation effects resulting from the lower total labour costs associated with temporary contracts. In absolute terms, this means between zero and 510,000 jobs out of the 2.7 million net jobs created were attributable to temporary contracts. Relative to the total growth in employment, these effects may have been strongest between 2002 and 2007. During the early surge in the use of temporary contracts,

\footnotetext{
${ }^{16}$ Firms would be more prone to offer permanent contracts to the more productive workers, which is not directly observed. Lass and Wooden (2017) used a quintile regression to analyse the wage penalty for temporary workers in Australia. They found that the wage penalty associated with a temporary contract was high among low-paid workers, while higher earners enjoyed a wage premium. The concentration of temporary workers in the lower tail of the wage distribution in Poland may explain why we find an average wage penalty rather than an average wage premium.

${ }^{17}$ Heckman and Pages-Serra (2000) did not account for the costs incurred by legal procedures.
} 
between zero and 478,000 jobs out of $1,750,000$ jobs created (27\%) could be attributed to the move to temporary contracts (Figure 6). Thus, the employment effects of the proliferation of temporary contracts may have been most important during the recovery from the early 2000 s recession.

Our results for the upper bound of the net employment effect imply that there was a relatively high degree of labour demand elasticity (-0.48). This value is at the lower end of the interval for labour demand elasticities [-446;.072] pointed out by the meta-analysis of Lichter et al. (2014), and is in line with the older findings [-0.75; -0.15] of Hamermesh (1993). The lower end of elasticities given by Lichter et al. (2014) corresponds to the net employment effect of 457,000 jobs in 2015. Taking into account both our calculations and the findings of the literature, we conclude that the upper limit of potential net employment effect was below $4 \%$ of dependent employment in 2015.

Figure 6. Possible range of net employment growth that can be attributed to the proliferation of temporary contracts in Poland between 2002 and 2015

Thousands of workers

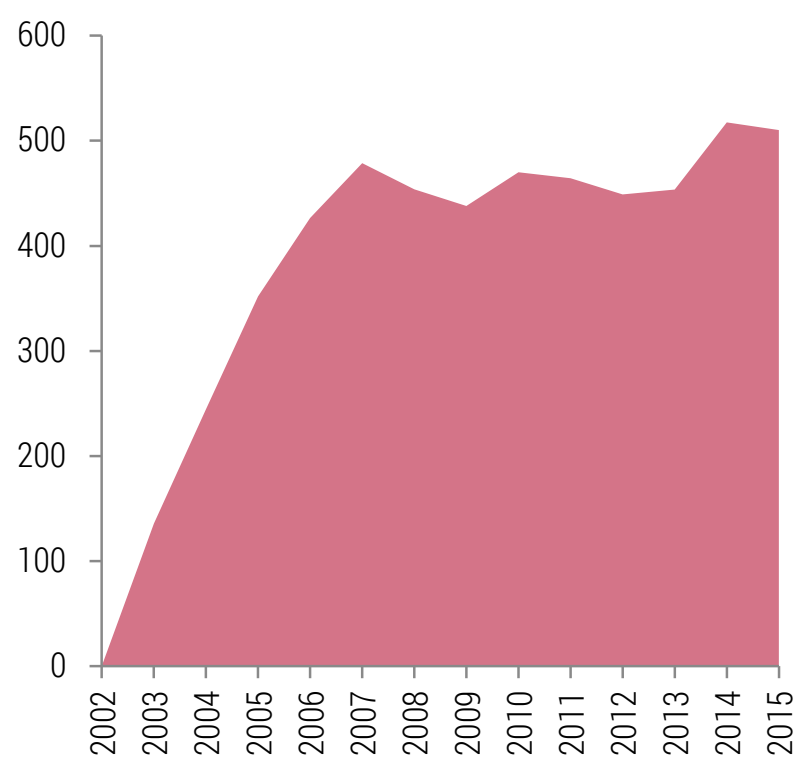

Share in net employment growth

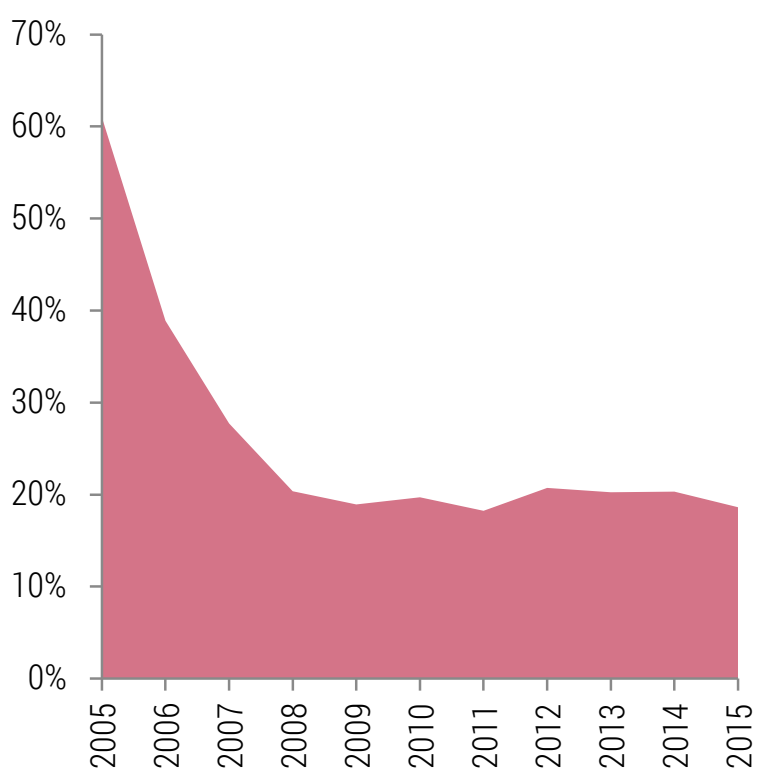

Source: Own calculations based on LFS data.

The extent to which permanent contracts were substituted with temporary contracts was substantial. This is demonstrated by the decomposition of total employment growth into changes in the number of temporary and permanent jobs that can be attributed to changes in aggregate demand or changes in the propensity to use temporary contracts (Figure 7). Assuming the upper bound of the potential net employment effect, we found that almost 1.1 million of the temporary jobs that existed in 2015 would have existed as permanent jobs if the propensity to use temporary contracts had remained constant at the 2002 level. This number would be even higher if the net employment effect had been lower. The growth in temporary contracts was largely driven by the increase in the propensity to use these contracts, regardless of the size of their potential employment creation effect. On the other hand, the improvement in the aggregate demand for labour was driving growth in permanent employment: despite the increase in the propensity to use temporary contracts, 727,000 permanent jobs were created between 2002 and 2015. 
Figure 7. Decomposition of employment growth in Poland between 2002 and 2015, under the assumptions of the upper bound of the potential net employment effect of the boom in temporary contracts

Thousands of workers

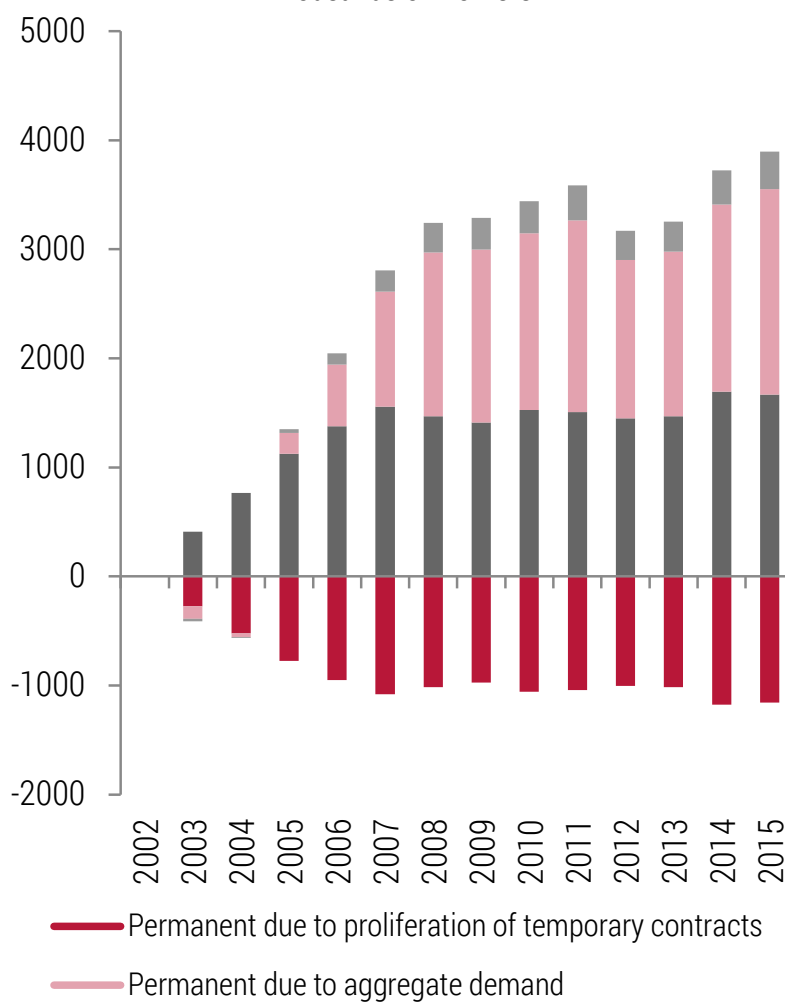

Share in net employment growth

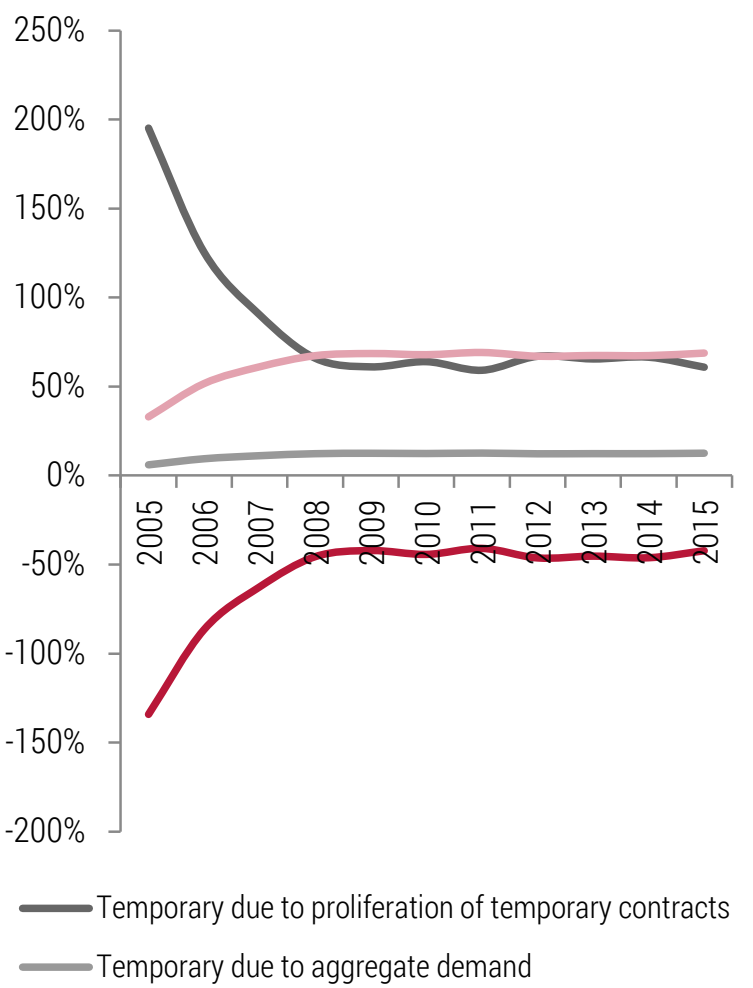

Source: Own calculations based on LFS data.

The spread of temporary contracts and the potential net employment creation effect were stronger among those groups of workers who were most exposed to unemployment risk, and whose bargaining power was the lowest: namely, poorly educated workers, as well as younger and older workers. For the upper bound of the potential employment effect, we found that among individuals with basic vocational education, job creation that could be linked to the rise in propensity to use temporary contracts accounted for up to $28 \%$ of temporary employment growth between 2002 and 2015; or for 4\% of total employment in that period (Figure 8). Among individuals with tertiary education, the corresponding shares were just $12 \%$ and $2 \%$, respectively.

The proliferation of temporary contracts was especially pronounced among individuals under age 25, who constituted the majority of labour market entrants. Among individuals aged 15-24, the upper bound of net job creation due to the rise in the propensity to use temporary contracts accounted for $29 \%$ of temporary employment growth between 2002 and 2015. In the 15-24 age group, temporary employment increased 50\% and permanent employment decreased $55 \%$. On the other hand, in the age group characterised by the lowest inflows to employment (55-64), the upper bound of net job creation did not exceed $5 \%$ of the growth in temporary jobs. This effect was larger (26\%) among individuals aged 45-54. 
Figure 8. The upper bound of net job creation due to the proliferation of temporary contracts in Poland between 2002 and 2015 , by education and age groups

By educational level

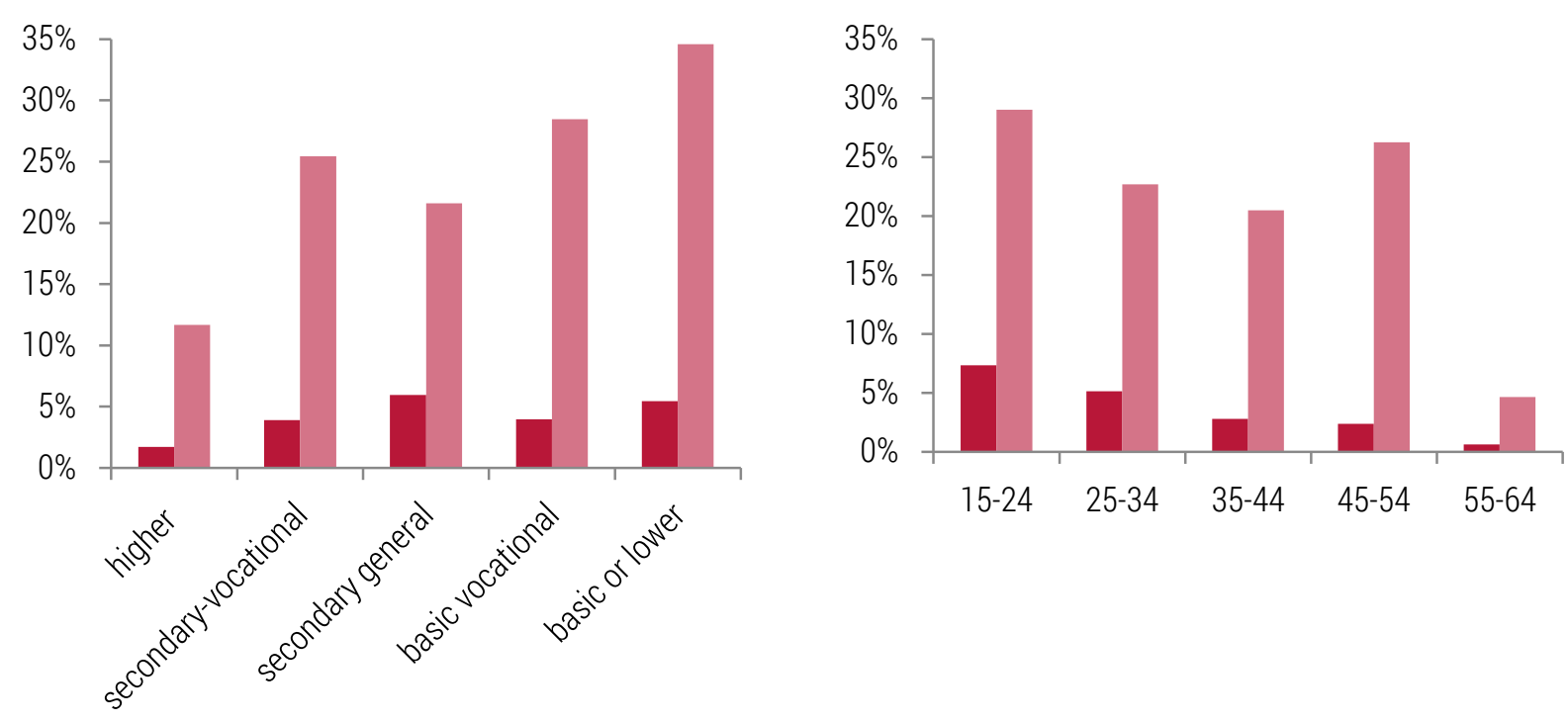

upper bound of net job creation due to proliferation of temporary contracts in employment 2015

- temporary jobs due to proliferation of temporary jobs in all new temporary jobs 2002-2015

Source: Own calculations based on LFS data.

\section{Summary and conclusions}

In this paper, we have offered a novel perspective on the temporary employment boom in Poland. We uncovered a persistent gap in job quality between temporary and permanent workers. The three key dimensions of this gap were found to be the quality of earnings, job security, and the quality of work scheduling. Differences in these dimensions were observed in both the descriptive and the regression analysis. We also found gaps in the incidence of long working hours and participation in training, but these differences were less pronounced. Our results indicate that job quality can add a new dimension to the debate on labour market segmentation: i.e., in addition to being less secure, the quality of temporary jobs tends to be lower.

Job quality in Poland has been gradually improving among both groups of workers, except in the dimensions of work scheduling quality and job strain, which deteriorated among temporary workers after 2010. Although the gaps between temporary and permanent workers generally narrowed over the study period, they remained substantial; in terms of both earnings quality and the incidence of long working hours, temporary workers lagged behind permanent workers by about seven years. Even during the most favourable periods (in 2006 and 2014), levels of job security for temporary workers were noticeably lower than in even the least secure period for permanent workers (in 2002). The gap becomes even wider if the coverage of redundant workers with unemployment benefits is taken into account.

Between 2002 and 2015, temporary employment in Poland more than doubled, and almost all of the net growth in employment was attributable to temporary jobs. However, it is unlikely that net employment growth would have been significantly lower if the increase in the incidence of temporary jobs had not happened. During that period, 
the macroeconomic performance of Poland was robust, there were substantial improvements in the educational attainment of the workforce, and retirement reforms boosted the labour supply of older workers.

It is important to point out, however, that over this period in Poland there were no full or even partial reforms of labour laws that might have widened the gap between the regulation of permanent and temporary contracts. These types of reforms have been shown to be key drivers of labour market segmentation in countries such as Spain (Dolado et al., 2002). The incentives to use temporary contracts were primarily related to the multiple forms of labour cost savings that these contracts allowed. The decreasing probability of labour inspections aimed at identifying the violations of rules pertaining to temporary contracts might have enhanced these incentives.

We put these cost differences stemming from wage penalties and differences in tax wedges and firing costs at the centre of our calculations of a possible range of potential employment creation effects resulting from the boom in temporary contracts. Since a rigorous analysis of the employment effects of temporary contracts is not possible due to the uniform application of regulations in Poland, we used a stylised labour demand model to identify these effects. The lower bound of the net employment effect is zero, as we cannot rule out the possibility that permanent workers were simply replaced with temporary workers. In order to provide the upper bound of the potential employment creation effect, we assumed that all of the labour cost savings offered by temporary contracts were used by firms to employ more people. Under these strong assumptions, we found that no more than $4 \%$ of dependent employment in 2015 could be attributed to the job creation effect of cheaper temporary contracts. If any of the labour costs savings offered by temporary contracts were channelled into higher firm profits or higher wages for permanent workers, the job creation effect would have been smaller; and, in the extreme case, close to zero.

Our findings stress the need to balance the potential benefits of cheaper, less regulated contracts with the multiple and often significant disadvantages temporary workers experience. Our findings stress the need to address the segmentation of Polish labour market. Labour inspection and improved enforcement of regulations could remedy this problem only in these cases in which low job quality results from non-compliance with regulations, for instance with minimum wage or with rules on working time. However, these cases are most likely rather rare. Lower job quality among temporary workers appears to be related to regulatory differences between temporary and permanent contracts (easier termination) and the allocation of temporary workers to jobs with lower quality. Therefore, a contractual arrangement which would bridge the gap in employment protection and hindered work organisation based on the type of contract, is needed. The introduction of a single contract that would provide workers with the same tenure with the same rights could be a solution. It would allow employers to screen workers and adjust employment levels. It would also allow workers to move from a less protected to a better protected position in the same firm. However, a single contract would discourage firms from allocating workers to better jobs and worse jobs depending on the type of a contract. 


\section{References}

Angrist, J., \& Krueger, A. B. (2001). Instrumental variables and the search for identification: From supply and demand to natural experiments (No. w8456). National Bureau of Economic Research.

Arak, P., Lewandowski, P., \& Żakowiecki, P. (2014). Dual labour market in Poland - proposals for overcoming the deadlock. IBS Policy Paper 1/2014.

Arranz, J.M., García-Serrano, C., \& Hernanz, V. (2017). Employment Quality: Are There Differences by Types of Contract?. Social Indicators Research, pp. 1-28. D01:10.1007/s11205-017-1586-4.

Auer, P., Berg, J., \& Coulibaly, I. (2005). Is a stable workforce good for productivity?. International Labour Review, 144(3), 319-343.

Baranowska, A., \& Lewandowski, P. (2007). Adaptability to economic changes. In: M. Bukowski (ed.), Employment in Poland 2007. Security on a flexible labour market. Warsaw: Ministry of Labour and Social Policy.

Barnow, B., Cain, G., \& Goldberger, A. (1981). Issues in the Analysis of Selectivity Bias. In: W.E. Stromsdorfer, G. Farkas (eds.), Evaluation Studies Review Annual, 5. Beverly Hills: Sage.

Bassanini A., \& Duval R. (2009). Unemployment, institutions and reform complementarities: Re-assessing the aggregate evidence for OECD countries. Oxford Review of Economic Policy, 25(1), 40-59.

Bentolila, S., \& Bertola, G. (1990). Firing costs and labour demand: how bad is eurosclerosis?. The Review of Economic Studies, 57(3), 381-402.

Bertola, G. (1990). Job security, employment and wages. European Economic Review, 34(4), 851-879.

Boeri, T., \& Garibaldi, P. (2007). Two Tier Reforms of Employment Protection: a Honeymoon Effect?. The Economic Journal, 177(521), F357-F385.

Boeri, T., \& Jimeno, J. F. (2005). The effects of employment protection: Learning from variable enforcement. European Economic Review, 49 (8), 2057-2077.

Cahuc, P., \& Postel-Vinay, F. (2002). Temporary jobs, employment protection and labor market performance. Labour economics, 9(1), 63-91.

Cazes, S., \& de Laiglesia, J.R. (2015). Temporary contracts and wage inequality. In: J. Berg (ed.), Labour Markets, Institutions and Inequality: Building Just Societies in the 21st Century. Edward Elgar Publishing.

Cazes, S., Hijzen, A., \& Saint-Martin, A. (2015). Measuring and Assessing Job Quality: The OECD Job Quality Framework. OECD Social, Employment and Migration Working Papers, No. 174, Paris: OECD Publishing. DOI: http://dx.doi.org/10.1787/5jrp02kjw1mr-en.

Chancellary of Prime Minister (2011). Młodzi 2011 (Youth 2011). Warsaw: Chancellary of Prime Minister.

Chłoń-Domińczak, A, \& Lis, M. (2013). Does gender matter for lifelong learning activity?. Neujobs Working Paper D16.2A.

Davoine, L., Erhel, C., \& Guergoat-Lariviere, M. (2008). Monitoring quality in work: European Employment Strategy indicators and beyond. International Labour Review, 147(2-3), 163-198. 
Gatti, R., Goraus, K., \& Morgandi, M. (2014). Balancing Flexibility and Worker Protection. Understanding Labor Market Duality in Poland. Washington D.C.: World Bank.

Goraus, K., \& Lewandowski, P. (2016). Minimum Wage Violation In Central And Eastern Europe. IBS Working Paper $3 / 2016$.

Hamermesh, D. H. (1993). Labor Demand. Princeton: Princeton University Press.

Hauff, S. \& Kirchner, S. (2014). Cross-national differences and trends in job quality, Diskussionspapiere des Schwerpunktes Unternehmensführung am Fachbereich BWL der Universität Hamburg Nr. 13

Heckman, J. J., \& Pages-Serra, C. (2000). The Cost of Job Security Regulation: Evidence from the Latin American Labor Markets. Journal of the Latin American and Caribbean Economic Association, 1, 109-154.

Hijzen, A., \& Swaim, P. (2007). Does offshoring reduce industry employment?. National Institute Economic Review, 201(1), 86-96.

Hopenhayn, H., \& Rogerson, R. (1993). Job turnover and policy evaluation: A general equilibrium analysis. Journal of Political Economy, 101(5), 915-938.

Hurley, J., Fernandez-Macias, E., \& Storrie, D. (2013). Employment Polarization and Job Quality in the Crisis: European Jobs Monitor 2013. Dublin: Eurofound.

Kalleberg, A. L., Reskin, B. F., \& Hudson, K. (2000). Bad jobs in America: Standard and nonstandard employment relations and job quality in the United States. American Sociological Review, 256-278.

Kamińska, A., \& Lewandowski, P. (2014). In-work poverty in Poland - diagnosis and possible remedies. Washington D.C.: World Bank.

Kanbur, R., \& Ronconi, L. (2016). Enforcement Matters: The Effective Regulation of Labor. Centre for Economic Policy Research Discussion Paper, No. 17098.

Kugler, A., \& Pica, G. (2003). Effects of Employment Protection and Product Market Regulations on the Italian Labor Market. IZA Discussion Paper, No. 948.

Lass, I., \& Wooden, M. (2017). The Structure of the Wage Gap for Temporary Workers: Evidence from Australian Panel Data. IZA Discussion Paper, No. 10670.

Lazear, E. (1990). Job Security Provisions and Employment. Quarterly Journal of Economics, 105(3), 699-726.

Lewandowski, P. \& Magda, I. (2017). Temporary employment, unemployment and employment protection legislation in Poland. In: M. Myant, A. Piasna (ed.), Myths of employment deregulation: how it has not created jobs and not reduced labour market segmentation. Brussels: ETUI.

Lewandowski, P., Stroński, K., \& Keister, R. (2016). Labour market segmentation and pensions in the Polish defined-contribution scheme. Problemy Polityki Społecznej. Studia i Dyskusje, 33(2), 111-137.

Lichter, A., Peichl, A., \& Siegloch, S. (2015). The own-wage elasticity of labor demand: A meta-regression analysis. European Economic Review, 80, 94-119. 
Maciejewska, M., Mrozowicki, A., \& Piasna, A. (2016). The silent and crawling crisis: international competition, labour market reforms and precarious jobs in Poland. In: M. Myant, S. Theodoropoulou, A. Piasna (ed.), Unemployment, internal devaluation and labour market deregulation in Europe. Brussels: ETUI.

Magda, I. (2016). Wykształcenie zawodowe, elastyczne zatrudnienie a podnoszenie swoich kwalifikacji (Vocational education, flexible employment and skills' upgrading). Edukacja 1/2016, 44-57.

Ministry of Administration and Digitization (2013). Długookresowa Strategia Rozwoju Kraju. Polska 2030. Trzecia fala nowoczesności (Long-term National Development Strategy. Poland 2030 Third Wave of Modernity). Warsaw: Ministry of Administration and Digitization.

Mondino, G., \& Montoya, S. (2000). The effects of labor market regulations on employment decisions by firms: Empirical evidence for Argentina. Research Network Working Paper, R-397. Inter-American Development Bank.

Muñoz de Bustillo, R., Fernández-Macías, E., Esteve, F., \& Antón, J. I. (2011). E pluribus unum? A critical survey of job quality indicators. Socio-Economic Review, 9(3), 447-475.

Nickell, S., Nunziata, L., \& Ochel, W. (2005). Unemployment in the OECD since the 1960s. What Do We Know?. Economic Journal, 115(500), 1-27.

OECD (2006). Economic Survey of Poland. Paris: OECD.

OECD (2012). Inequality in labour income - What are its drivers and how can it be reduced?. OECD Economics Department Policy Notes, No. 8.

OECD (2014). OECD Economic Surveys: Poland 2014. Paris: OECD Publishing. DOI: http://dx.doi.org/10.1787/eco_surveys-pol-2014-en.

OECD (2014). OECD Employment Outlook 2014. Paris: OECD Publishing. DOI: http://dx.doi.org/10.1787/empl_outlook-2014-en.

Pereira, S. C. (2003). The impact of minimum wages on youth employment in Portugal. European Economic Review, 47(2), 229-244.

Sondergaard, L., Murthi, M., Abu-Ghaida, D., Bodewig, C., \& Rutkowski, J. (2012). Skills, Not Just Diplomas: Managing Education for Results in Eastern Europe and Central Asia. Washington D.C.: World Bank Publications.

Van der Klaauw, B. (2014). From micro data to causality: Forty years of empirical labor economics. Labour Economics, 30, 88-97.

World Bank (2017). Lessons from Poland, Insights for Poland. Washington D.C.: World Bank. 


\section{Appendix}

\section{Derivation of the net employment effect}

With the assumption discussed in section 4.2, the model is written as:

$$
\begin{gathered}
\frac{d T}{d t}=a_{T} x+y_{T} \frac{d \lambda}{d t} \\
\frac{d M}{d t}=a_{M} x+y_{M} \frac{d \lambda}{d t} \\
y_{T}=-\frac{L C_{M}}{L C_{T}} y_{M} \\
a_{T}=1-a_{M}=\frac{T}{T+M}
\end{gathered}
$$

Rearranging leads to:

$$
\begin{gathered}
y_{M}=\left(\frac{d M}{d t}-a_{M} x\right) / \frac{d \lambda}{d t} \\
x=\left(\frac{d T}{d t}+\frac{L C_{M}}{L C_{T}} \frac{d M}{d t}\right) /\left(1+a_{M}\left(\frac{L C_{M}}{L C_{T}}-1\right)\right)
\end{gathered}
$$

The counterfactual scenario describes the evolution of private sector employment, assuming that no switch in preferences took place $\left(\frac{d \lambda}{d t}=0\right)$. It terms of our specification, the counterfactual is expressed as the sum of the change in permanent and temporary jobs due to changes in the acceptance of temporary contracts:

$$
\frac{d \hat{E}}{d t}=y_{T} \frac{d \lambda}{d t}+y_{M} \frac{d \lambda}{d t}=\left(1-\frac{L C_{M}}{L C_{T}}\right) y_{M} \frac{d \lambda}{d t}=\left(1-\frac{L C_{M}}{L C_{T}}\right)\left(\frac{d M}{d t}-a_{M} x\right)
$$




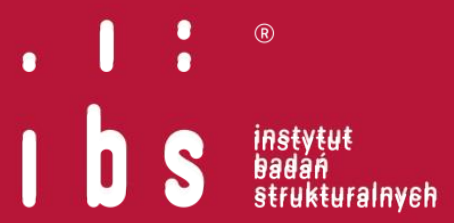

www.ibs.org.pl 